\title{
Saga og eiginleikar danskra íbúðalána
}

\author{
Helgi Tómasson ${ }^{1}$
}

\begin{abstract}
Ágrip
Danskur skuldabréfamarkaður er mjög próaður og hlutfallslega stór miðað við umfang hagkerfisins. Rætur hans liggja í langri regluhefð stofnana sem sýsla með veðlán. Í pessari grein er rakin saga tegundar skuldabréfa sem ganga undir heitinu realkredit-skuldabréf. Pannig bréf eiga sér langa hefð í Danmörku en eru lítt pekkt utan Danmerkur. Markmið útgáfunnar er að miðla markaðsvöxtum beint til lántaka pannig að peir nái sem hagstæðustum vöxtum. Pessi tegund skuldabréfa er notuð til að fjármagna fasteignir, bæði í íbúðar- og atvinnuhúsnæði. Dregin er upp mynd af 200 ára próun vaxta og fjármálaafurðum. Tengslum vaxtapróunar, greiðslubyrði lána og fasteignaverðs á tímabilinu 1992-2013 er lýst og borið lauslega saman við íslenska próun. Nokkrir pættir í samspili við bankakerfi og Evrópusambandið eru raktir.
\end{abstract}

\begin{abstract}
The Danish bond market is highly developed and relatively large compared to the size of the Danish economy. Its roots lie are based on a long tradition of institutions that deal with mortgages. This paper gives a review of the history of a particular type of bond which are called real-credit bonds. These bonds have a long tradition in Denmark but are virtually unknown outside of Denmark. The aim is to link the bond market directly to the borrower and ensure that they obtain best possible interest rates. This type of bond is used to finance real estate, both for domestic and industrial investment. A review of 200 years of development in interests and financial products is given. A particular review of the period 1992-2013 is given and compared briefly to the development in Iceland in that period. Some comments on the interaction between the banking system and the European Union are given.
\end{abstract}

JEL flokkun: B15, B25, R30

Lykilorð: Veðlán, skuldabréf, fasteignir, stofnanaumhverfi

\footnotetext{
${ }^{1}$ Helgi Tómasson, prófessor í hagrannsóknum og tölfræði við Háskóla Íslands. Höfundur pakkar Jens Lunde við Handelshøjskolen i København leiðsögn um eðli RK-starfseminnar. Einnig pakka ég góðar móttökur hjá Realkreditrådet og Realkreditforeningen. Alpingi er pakkað fyrir að hafa veitt mér aðstöðu í Jónshúsi. Ritstjórn er pakkað fyrir góðar ábendingar.
}

This work is licensed under a Creative Commons Attribution 4.0 License. 


\section{Inngangur}

Eftir óróa á skuldabréfamarkaði seinni hluta árs 2008 hefur pað vakið athygli að skuldabréfamarkaður Danmerkur virtist standast pau áföll sem urðu víða um heim. Í pessari grein er leitast við að greina eiginleika pess markaðar til að varpa ljósi á eiginleika dansks skuldabréfamarkaðar og hvort dönsk stofnanauppbygging hafi hugsanlega verið sérstaklega hæf til að veita viðspyrnu. Stofnanaumhverfi er ekki auðvelt að flytja á milli landa.

Í Danmörku er rekinn sérstakur skuldabréfamarkaður sem hefur pað að markmiði að miðla fjármagni milli fjárfesta og kaupenda íbúðarhúsnæðis. Formið á skuldabréfunum gengur undir nafninu Realkredit (RK). Annað meginmarkmið pessarar greinar er að setja danskt húsnæðislánakerfi nútímans í sögulegt samhengi. Hitt meginmarkmið greinarinnar er að lýsa helstu atriðum í stöðu RK-kerfisins í Danmörku í upphafi 21. aldar. Gert er ráð fyrir að Íslendingar eins og aðrir utan Danmerkur viti lítið um tilurð og eiginleika RK-kerfisins. Hugmyndin með ritun pessarar greinar er að veita Íslendingum örlitla innsýn í petta einstaka danska fyrirbæri. Slíkt gæti auðveldað upplýsta ákvörðun um pað hvort taka megi upp hugmyndir úr RK-kerfinu í lánaumhverfi framtíðarinnar. Hugtökin eign og skuld eru fyrirferðamikil í hagfræði og lögfræði. Áherslan í pessari grein er á samspil hefða og samfélags en ekki er farið út í hagfræðilegar eða lögfræðilegar greiningar.

Fjárfesting í fasteign, landi eða húsnæði er stöðutaka til langs tíma. аð er einnig fyrir marga pað stór fjárfesting að fjárfestirinn parf að leita til stofnana eða samtaka til að fá pá fyrirgreiðslu sem nauðsynleg er til að fjárfestirinn lifi pað að fá arð af fjárfestingunni, t.d. að geta búið í góðu húsnæði. Samfélög hafa pví próað með sér kerfi stofnana sem miðla og veita aðgang að fjármunum svo fjárfestirinn nýti tímann á sem hagkvæmastan hátt. Lánveitandinn vill að sjálfsögðu fá fjármuni sína til baka og pví má segja að fjárfestirinn sé að kaupa traust og tíma. Рað veitir lánveitandanum aukið öryggi að hann geti tekið einhvers konar tryggingu, í dag oft kallað veð, í peirri eign sem fjárfest er fyrir.

Danmörk er land með rótgróna stofnanauppbyggingu og par eru í dag umsvifamiklar lánastofnanir sem sérhæfa sig í að miðla lánsfé til fjárfestinga í fasteignum. Pessar stofnanir hafa próast til hliðar við hefðbundið bankakerfi sem líkist pví sem tíðkast í mörgum löndum. Dönsku stofnanirnar sem sérhæfa sig í lánum til fasteignakaupa ganga undir heitinu realkredit (RK)-félög/fyrirtæki. Pað heiti rekur uppruna sinn til 19. aldar pegar ákveðin félög sérhæfðu sig í að veita lán á „fyrsta forgangi"(sjá nánar í kafla 2). Lán sem veitt voru á „öðrum forgangi" gengu undir heitinu hypotek (HT)- lán. Í byrjun 19. aldar voru hugtökin eignaréttur og veðréttur frábrugðin pví sem síðar varð. Í dag gengur öll pessi starfsemi undir heitinu realkredit. RK-kerfið stóðst fjármálakreppuna 2008 í peim skilningi að viðskipti með skuldabréf stöðvuðust ekki (Lunde, 2012b). Stýrivextir Seðlabanka Danmerkur hafa á tímabilinu 2008-2014 verið í sögulegu lágmarki og skuldabréfavextir einnig. Pessir lágu vextir hafa haft pað í för með sér að höfuðstóll skulda, (t.d. sem hlutfall af landsframleiðslu), er mjög hár. Pess vegna er ákveðinn ótti við pað hvað gerist pegar vextir verða aftur „eðlilegir". Hugsanlegt er talið að hökt komi á skuldabréfaútboðin og ávöxtunarkrafa snarhækki. Pessi ótti hefur leitt pjóðping Danmerkur (Folketinget) til að setja sérstök lög (1. apríl 2014) sem kveða á um pað að vextir megi ekki hækka meira en 5 prósentustig á ári. Pessi lagasetning og miklar skuldir danskra heimila og fyrirtækja hafa vakið athygli erlendis og tímaritið Economist (2014, 19. apríl) notaði fræga tilvitnun úr Hamlet, „,something is rotten": Denmark's property market is 
built on rickety foundations ${ }^{2}$. Danir eru stoltir af hefð sinni í fjármögnun fasteigna og munu leggja sig fram um að halda sérstöðu sinni innan Evrópusambandsins.

Í upphafi 19. aldar voru skilmálar um að bæði lánveitandi og lánpegi gætu sagt upp lánasamningnum með eins greiðslutímabils fyrirvara. Рað voru tvö greiðslutímabil á ári. Lánpegi gat pví purft að endurfjármagna lánið í skyndi ef lánveitandi taldi sig purfa á peningunum að halda. Í raun hafði petta minni pýðingu en ætla mætti pví að í litlu samfélagi vissu lánveitandi og lánpegi hver af öđrum. Lánpegi gat áætlað hvort lánveitandinn væri líklegur til að purfa á fjármagni að halda í bráð. Einnig að ef lánveitandi yrði uppvís að pví að segja upp láni án góðrar ástæðu, væri hugsanlega að reyna að komast yfir eignir lántaka á nauðungaruppboði, pá ætti sá lánveitandi ekki góða möguleika á að fá trúverðuga lántakendur í framtíðinni. Á peim tíma voru lögbundnir hámarksvextir á RK-skuldabréfum $4 \%$ og pví líklega ekki mikið svigrúm til spákaupmennsku með vexti. RK-félögin voru pví ekki að verðleggja áhættu vegna vaxtabreytileika heldur lögðu pau áherslu á að tryggingin (í dag veðið) væri sem allra öruggast. Frávik frá pessum hámarksvöxtum mynduðust á eftirmarkaði með skuldabréf. Lengi var langtíma fastvaxtalán með uppgreiðslurétti af hálfu lántaka aðalafurð RK-fyritækja.

Próun RK-kerfisins hefur leitt af sér pá stöðu að Danmörk hefur nú í upphafi 21. aldar einn próaðasta skuldabréfamarkað heims. RK- og HT-félögin hafa próast og skilin milli fyrsta og annars forgangs hafa dofnað. Í fyrstu voru RK og HT-félögin samábyrgðar/samvinnufélög. Petta eru ekki lengur samábyrgðarfélög par sem meðlimirnir taka áhættu á pví að aðrir félagsmenn borgi. Nú eru petta hlutafélög sem bæta áhættupóknun inn í verðskrána og peir sem vilja taka áhættu geta keypt sig inn í hlutafélagið. Skuldabréf nýju RK-hlutafélaganna njóta enn ákveðinnar lagalegrar sérstöðu og eru talin sérlega örugg eign. Pessi staða ásamt traustri stöðu danskra ríkisfjármála, trú markaðarins á tengingu danskrar krónu við evru og að á 200 árum hefur pað aldrei gerst að eigandi RK-skuldabréfs hafi fengið skerta greiðslu, gerir pað að verkum að RK-fyrirtækin bjóða einhverja lægstu vexti til húsnæðislána sem um getur í heiminum. Totalkredit(hluti af Nykredit), segist bjóða heimsins bestu lán (11.02.2015 á https://www.totalkredit.dk/om-totalkredit/fakta-om-totalkredit/). Ávöxtunarkrafa RKskuldabréfa hefur lengst af verið óverulega hærri en ávöxtunarkrafa danskra ríkisskuldabréfa (sjá t.d. gagnabanka á heimasíðu Danska seðlabankans, http://www.nationalbanken.dk). Í samræmi við venjulegar núvirðingarformúlur hefur hið lága vaxtastig prýst upp verði fasteigna í Danmörku. Раð gerir pað аð verkum að danskir húsnæðiseigendur eru meðal skuldugustu húseiganda heims (Lunde, 2012a).

Söguleg atriði greinarinnar í 2. kafla eru að miklu leyti byggð á bók Møller \& Nielsen (1997) um 200 ára sögu RK. Nokkrum afurðum RK-fyrirtækja og eiginleikum peirra er lýst í 3. kafla. RK-félögin veittu lán gegn tryggingu í eign, p.e. lánuðu fyrirfram ákveðið hlutfall, í byrjun $60 \%$, af virði eignar. Petta hlutfall hefur undanfarin ár verið $80 \%$. Til að hægt sé að tala um eign parf að vera til einhver opinber skilgreining eða skrá um lánshæfar eignir og pað parf einhvers konar verðmatskerfi. Lausn Dana á pessum vanda er lauslega rakin í kafla 4. Próun raunvaxta (nafnvaxta að frádreginni verðbólgu) í Danmörku, ásamt lauslegum samanburði við íslenska próun, er rakin í 5. kafla. Í kafla 6 er velt upp umræðupunktum og teknar saman nokkrar ályktanir um stöðu RK-kerfisins á 21. öld. Einnig eru ræddar hliðstæður við íslenskt regluumhverfi og hvers vegna RK-hugmyndin er ópekkt utan Danmerkur.

\footnotetext{
2 Eignamarkaður Danmerkur er byggður á ótraustum grunni.
} 


\section{Saga RK-hugmyndarinnar}

\subsection{Upphaf og grundvallaratriði}

Saga RK-skuldabréfa hófst árið 1795 pegar afstaðinn er (enn einn) stórbruni í Kaupmannahöfn. Pá bindast menn samtökum og mynda félög sem hafa pað að markmiði að afla fjár til endurbygginga. Petta voru eins konar samvinnu- eða samábyrgðarfélög par sem lántakendur gengu í ábyrgð hver fyrir annan (solidarisk hæftelse) og gáfu út sameiginleg skuldabréf. Pessi félög voru kölluð real-kredit foreninger (RK-félög). Hugmyndin var að ef einn í félaginu gæti ekki borgað pá myndu aðrir félagsmenn hlaupa undir bagga og pannig var áhætta lánveitenda mjög lítil. Gefin voru út sérstök skuldabréf sem höfðu forgangsstöðu. RK-skuldabréfin mátti í upphafi nota fyrir allt að $60 \%$ af virði eignar og höfðu svokallaðan fyrsta forgang. Hér er notað hugtakið fyrsti forgangur, pví upp úr aldamótunum 1800 var petta að einhverju leyti frábrugðið pví sem í íslenskri lögfræði í dag er kallaður fyrsti veðréttur. Pegar leið á 19. öldina kom í ljós að pörf var á frekari fjármögnun og voru pá stofnuð félög sem sérhæfðu sig í lánum á öðrum forgangi. Pau félög voru kölluð hypotek-foreninger (HT). Síðasti hluti fjármögnunar purfti alltaf að koma frá húseigandanum (landeigandanum) sjálfum í formi eigin framlags, bankaláns, arfs eða sparifjár.

Notkun á hugtakinu forgangur kallaði á sérstök lög sem sett eru í danska ríkinu á seinni hluta 19. aldar. Petta mótar einnig íslensku veðréttarlögin sem eru að uppistöðu til frá árinu 1887 (Porgeir Örlygsson, 2002). Í upphafi var veðréttur (panteret á Norrænu) aðallega handveð, p.e. að lántakinn gat ekki haft veðið í vörslu sinni fyrr en skuld var greidd. Porgeir Örlygsson rekur próun hugtaksins sjálfsvörsluveð. Eftir poí sem atvinnurekstur varð umfangsmeiri varð til ný tegund veðréttinda ... Veðsali gat haldið veðinu hjá sér meðan hann stóð í skilum með greiðslu afborgana og vaxta (Porgeir Örlygsson, 2002, bls. 23 og fyrirlestranótur). Í Norrænni orðabók virðist hypotek-hugtakið vera svipað. Hypotek (av gresk hypotheke 'underlag, pant') eller hypotekarisk pant er en form for pant der objektet ikke overføres til pantehaver (Babylon 10: Free Online Dictionary, 2014) ${ }^{3}$. RK-félög fengu í upphafi forgang umfram HT-félög. P.e. handhafar RK-bréfa fengu sínar kröfur á undan handhöfum HT-bréfa (nútíma veðréttur var ekki skilgreindur í upphafi 19. aldar). Hér eftir er pessi trygging kölluð veð, pó að pað hafi ekki lagalega skírskotun allt tímabilið.

Pó að RK eigi sér 200 ára sögu pá er víðsfjarri að engu hafi verið breytt á peim tíma. Hliðstæð próun hafði verið í Prússlandi, einnig eftir stóráfall, 7 ára stríðið 1756-1763. Par var komið á lánamiðlun sem var kölluð „landschaften". Sú hugmynd var sett fram af kaupmanni að nafni Büring og framkvæmd undir stjórn Friðriks mikla. Á fyrri hluta 19. aldar tileinkuðu Danir sér pýsku hugmyndirnar og próuðu endurbætur. Í sögulegri lögfræðiritgerð ber Ditlev (2009, bls. 7) saman próun danskra og pýskra laga um skuldabréf sem hann segir að séu elstu pess háttar lög í Evrópu. Pýska útfærslan með „pfandebriefe” hafi hins vegar orðið ráðandi í mörgum Evrópulöndum. Hann skýrir petta með stærðarmun landanna. Vitnað er til athygliverðrar bókar eftir danskan hagfræðing, A.F. Bergsøe, „Motiveret Udkast til en Creditforening for danske Grundbesiddere"(Bergsøe, 1839). Bergsøe lagði árherslu á jafnvægi milli skuldabréfaútgáfu og útlána og talaði fyrir pví að lán væru borguð niður. Áherslan á jafnvægi (balance-prinsippet) hefur verið einn af hornsteinum RK-skuldabréfaútgáfu æ síðan. Jafnvægisreglan kveður á um pað að greiðsluskylda skuldarans skuli vera nákvæmlega í takt við greiðsluflæði til lánveitanda. P.e. lánamiðlunarstofnunin tekur ekki stöðu í

${ }^{3}$ Orðið hypotek kemur úr grísku og lýsir pví að hluturinn sem lánað er út á purfi ekki að vera í vörslu lánveitanda. 
skuldabréfunum. Síðan er tæknilegt atriði að útfæra hvað „,nákvæmlega” pýðir. Bergsøe benti á að verðmæti undirliggjandi veðs gæti rýrnað með tímanum og pví ætti lántaki að borga lán niður. Sú skoðun hans náði ekki sömu fótfestu og jafnvægishugmyndin. Bergsøe taldi að lánveitandi ætti ekki að purfa að vakta veðið að eilífu en eigi að síður urðu lánasamningar mjög langir, 50-60 ár. Bergsøe talar fyrir pví að kerfið skuli vera sjálfbært án afskipta ríkisvaldsins. Að hálfu ríkisvaldsins var innbyggð tortryggni gagnvart svona hugmyndum. Par blönduðust saman samskipti konungs, aðals, bænda og borgara. Ýmsir jarðeigendur töldu pað auka verðmæti lands síns ef bændur ættu pess kost að fjárfesta í endurbótum. Konungsvaldið treysti ekki jarðeigendum, efaðist um hæfni bænda og vildi ekki sitja uppi með stórskuldugan bændaskara ef illa færi. Bergsøe talaði fyrir pví að lánastofnanir skyldu starfa í öllu landinu til að ná hagkvæmni stórrekstrar. Yfirvöld voru ósammála og töldu að pað ætti ekki að vera of langt á milli lánadrottins og skuldara. Pannig gætu peir betur haft eftirlit hvor með öðrum. Útfærslan var pví lengi vel hólfuð, bæði landfræðilega og einnig eftir pví hvort fjárfestingin var í borg eða sveit og einnig eftir pví hvernig nota átti fjárfestinguna. Sum félög gátu aðeins lánað í viðurkenndum kaupstöðum (danskt stjórnsýsluhugtak), aðrir bara til landbúnaðar, o.s.frv. Vísbendingu um margbreytileika RK- og HT-félaga má lesa úr töflu 1. Nokkur ártöl úr sögu kerfisins eru sýnd í töflum 2 og 3. 
Tafla 1. Nöfn og stofnár nokkurra gamalla RK- og HT-félaga.

Nöfnin gefa vísbendingu um staðsetningu og hlutverk (Boligministeriet, 1987).

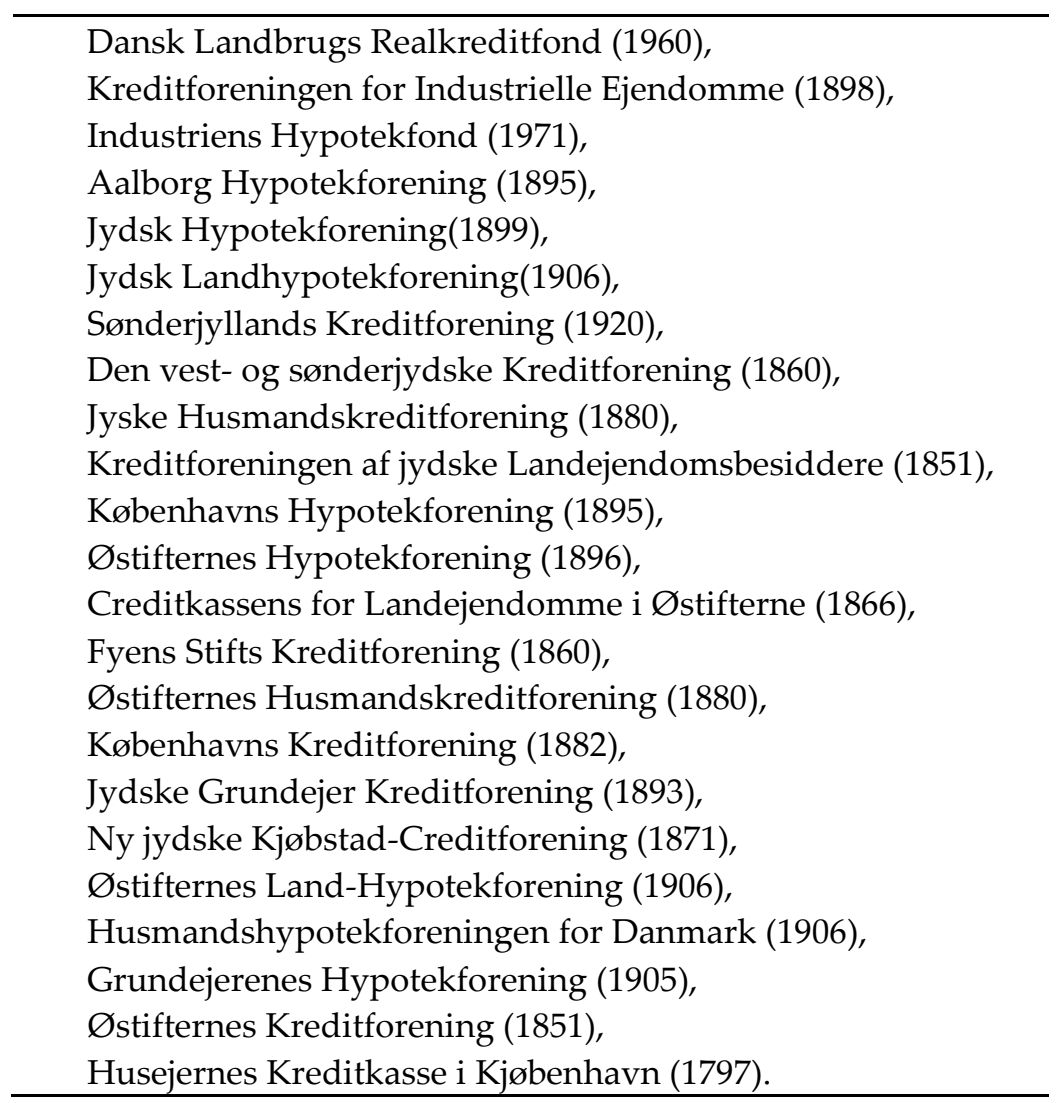

\subsection{Stjórnarskrá og félagafrelsi}

Í upphafi 19. aldar ríkti einveldi konungs, félagafrelsi var takmarkað og ný starfsemi purfti sérstaka blessun konungs. Ný stjórnarskrá í Danmörku 1849, afnám einveldi konungs og heimild til félagafrelsis breytti aðstæðum m.a. á lánamarkaði mikið. Eftir petta verður heimilt að stofna samvinnufélög um ábyrgðir og félög um veitingu lána. Tímabilið 1850-1860 einkennist af grósku í nýsköpun í félagamyndun. Félagafrelsið pýddi að menn gátu valið sér félaga. Bændur gátu t.d. talið að pað væri áhættusamara að lána til fjárfestinga í borgum en sveitum. Í félögum par sem samábyrgð ræður er erfitt að ná samkomulagi um pað hvernig lána skuli til misáhættusamrar starfsemi. Pannig lá í samábyrgðarhugmyndinni eins konar sjálfvirkni um að félögin yrðu mjög mörg. Peir félagsmenn sem pegar voru komnir með lán og hugsanlega byrjaðir að borga niður voru tregir til að ganga í ábyrgð fyrir nýja unga meðlimi. Að lokum stöðvaði pjóðping Danmerkur frekari fjölgun félaga með pví að skylda pau til að vera með flokka eða raðir (serier) af skuldabréfum, pannig að lántakendur innan hverrar raðar yrðu einsleitari og að ábyrgðin væri meiri innan raðar og við nálægar raðir. Рað lá í hlutarins eðli að á meðan nýjasta röðin var mjög lítil pá bar röðin sem var næst peim meiri ábyrgð. RK-félögin innheimtu umsýslupóknun (bidrag) sem varð grundvöllur myndunar eiginfjár, sem nota mátti sem tryggingu gegn útlánatöpum, pannig að síður reyndi á samábyrgðina.

Petta frjálsræði sem parna tíðkaðist er skert í dag en með lögum sem sett voru 1989 er bannað að stofna ný RK-samvinnufélög. Með peim lögum var ákveðið að ný RK-félög yrðu á hlutafélagaformi, eldri samvinnufélögum var leyft að starfa áfram. Próun leiddi í ljós að öll 
RK-starfsemi varð á hlutafélagaformi. Рað síðasta, Dansk landbrugsrealkreditfond, varð DLR A/S árið 2001 (eftir að einkaréttur á ákveðnum landbúnaðarviðskiptum var afnuminn).

Раð má segja að kerfið í dag (2016) sé nánast ópekkjanlegt séð með augum peirra sem stofnsettu kerfið. Í upphafi og lengi fram eftir 20. öld voru RK stofnanirnar samvinnufyrirtæki og rekin á einhvers konar félagslegum (foreningsbaseret) grunni. Upp úr 1950 var tekið fyrir að meðlimir fengju fé sitt til baka við uppgreiðslu láns og útgöngu úr félaginu. Eftir 1970 breytist eðli RK-kerfisins og fram koma nýjar stofnanir sem líkjast meira hefðbundnum fyrirtækjum sem hafa hámarkshagnað að leiðarljósi. Samábyrgðarkerfið pótti hafa gengið sér til húðar. RKfélögin voru mörg og í sumum voru til umtalsverðir sjóðir og áhættudreifing ójöfn. Áhætta RK-fyrirtækis vegna nýrra lána var meiri en undirliggjandi lánasafns. Hlutafélagaformið par sem hluthafar einir bæru ábyrgð pótti vera kall tímans. RK fyrirtækjum fækkaði og einstökum lántakendum dugði fyrirgreiðsla frá einu RK-fyrirtæki en purfti minnst frá premur aðilum áður (BRFKredit, 2014). Nú (2016) eru mörg peirra nátengd almennum viðskiptabönkum.

Møller \& Nielsen (1997) rekja pætti úr sögu dansks fjármálakerfis og reyna jafnframt að tengja hana við hagsögu og greina hversu gagnleg RK-hugmyndin hefur verið fyrir danskt samfélag. Peir benda á að pó að efnahagsreikningar RK-stofnana hafi vissulega verið stórir, pá sé mikilvægi peirra e.t.v. alls ekki í hlutfalli við stærðina. Hlutverk peirra sé að miðla kredit af einföldustu gerð, p.e. láni með veði í fasteign. Рað sé e.t.v. sú lánastarfsemi sem einfalt sé að skipuleggja án milligöngu sérhæfðra aðila.

Pessi félög voru langtímum saman mjög varkár í útlánum og dugðu lán frá peim ein og sér ekki til að fjármagna húsnæðiskaup. Í löggjöf frá 1850 var sett pak á RK-lán sem var 60\% af matsvirði eignar. Afganginn purfti að fjármagna með bankalánum, sérstökum veðbréfum (pantebrev) o.s.frv. RK-stofnanirnar leystu pví einungis hluta fjármögnunarvandans. Pví voru stundum í boði viðbótarlán frá opinberum sjóðum. Slíkt kallaði á lagskipta stjórnun í lánamálum sem varla getur verið samfélagslega hagkvæm. Møller \& Nielsen (1997) kalla petta (bls. 16) „insider-outsider" vandamál. Árið 1997 lýsa peir stöðunni pannig að nú standi RKformið frammi fyrir stórum áskorunum. Krafan um að öll skuldabréf séu uppgreiðanleg geti ekki verið samfélagslega hagkvæm. Viðskiptakostnaðurinn við slíkt sé of hár og varan verði ógagnsærri. Verðlagning uppgreiðsluréttarins byggir á flóknum tölfræðilegum líkönum. Annað vandamál séu deilur stjórnmálamanna um hvort henti betur samvinnufélagsform eða hlutafélagsform og hvort löggjafinn skuli beita sér varðandi val á formi.

\subsection{Alpjóðleg samskipti}

Á vissu skeiði (í kringum 1900) var reynt að selja skuldabréfin utan Danmerkur. Á peim tíma vanmátu menn gengisáhættuna. Skuldabréfin voru færð í aðra gjaldmiðla í trausti fastgengis. Um aldamótin 1900 var 1/7 hluti (meira en um og eftir aldamótin 2000) útistandandi skulda í annarri mynt en dönskum krónum. Verðbólga á 19. öld var óveruleg, innbyrðis gengi gjaldmiðla stöðugt og menn pví lítt meðvitaðir um atriði eins og gengisáhættu og verðbólguáhættu. Petta meðvitundarleysi leiddi til pess að Danir gáfu út skuldabréf par sem eigandinn gat valið í hvaða gjaldmiðli vextirnir skyldu borgaðir. Gjaldmiðlagengi vaxtanna var ákveðið á útgáfudegi skuldabréfsins. Í heimstyrjöldinni 1914-1918 riðlast petta og upp komu vandamál með tvímyntarskuldabréfin pví menn völdu að fá vextina greidda í verðmætasta gjaldmiðlinum. Árið 1923 voru tvímyntkerfisskuldabréf bönnuð (Møller \& Nielsen, 1997). Trú manna á fast gengi og enga verðbólgu var brostin.

Eftir tilkomu evrunnar hafa RK-fyrirtækin gefið út skuldabréf í evrum og var sagt að menn reiknuðu með að vextir í evrunni yrðu lægri en í dönsku krónunni vegna smæðar krónunnar. Ávöxtunarkrafa danskra RK-skuldabréfa í evrum hefur verið lægri en í dönskum 
krónum meirihluta pess tímabils sem evran hefur verið til. Раð gæti verið vísbending um að menn hafi talið evruna betri gjaldmiðil. Árin 2012-2014 var ávöxtunarkrafan í dönskum krónum yfirleitt lægri.

Samkvæmt Realkreditrådet (2012) eru erlendir fjárfestar á 21. öld eigendur að 10-15\% útistandandi RK-bréfa, p.e. heldur minna en fyrir 100 árum. Bankar, tryggingafélög og lífeyrissjóðir eiga um 75\% og einstaklingar um $8 \%$.

\subsection{Kreppur og inngrip stjórnvalda}

Árin upp úr 1930 er talað um að samkeppni sé of mikil á milli RK-fyrirtækja. Realkreditkommissionen ${ }^{4}$ segir lántakendur hafa getað gengið á milli fyrirtækja. Petta hafi leitt til pess að of mikið hafi verið lánað út. Pessi umræða kom upp eftir útlánatöp af stærðargráðunni 0,5-2,0\% á árunum upp úr 1930. Рað er ekki gott að segja hve tapið varð að lokum mikið pví kröfuhafar geta reynt að innheimta í 20 ár eða jafnvel lengur. Petta var engan veginn sérdanskt fyrirbæri. Víða um heim höfðu útlán verið of mikil og pví orsakaði verðfallið vegna heimskreppunnar útlánatöp víða. Viðamikil lagabreyting var pví gerð árið 1936. Hluti vandans var alpjóðlegur og rekur Callø (1932) hvaða áhrif hagsveiflur og rangar áherslur í útlánum hefðu haft á stöðu RK-félaganna. Hann taldi upp kreppur á 19. öld sem höfðu leitt til útlánatapa hjá RK-félögum og sér í lagi hvernig ríkið hefði purft að bjarga HT-félögum. Sérstök lög voru sett um HT-félög 1936 (sem höfðu verið starfrækt frá 1895). Síðast reyndi á samábyrgðina á pessu tímabili. Callø nefndi of mikil útlán til landbúnaðar, dreifðra byggða og sveitarfélaga. Hann nefndi einnig ofmat eigna og oftrú á hæfni matsmanna eigna, hann sagði: naar man ser Resultaterne af Vurderingsmændenes Arbejde maa man sige at den hjælper ikke meget ${ }^{5}$, og sagði að vinna matsmanna hjálpaði ekki alltaf mikið (Callø, 1932, bls. 296). Viðbrögðin voru á pá leið að draga úr samkeppni og úthluta einstökum RK-félögum sérstökum svæðum og skilgreindum verkefnum.

Tímabilið frá 1965 til 1980 einkenndist af inngripum í markaðsferlið. Á peim árum var sú hugsun að láta vextina ákvarðast á uppboði á markaði ekki ráðandi. Nefnd sem starfaði á peim tíma taldi að hemja ætti skuldabréfaútgáfuna, bæði upphæðina og tímalengdina. Árið 1970 var mikil kerfisbreyting, stofnunum var fækkað, HT og RK starfsemin voru sameinuð.

Раð var ekki fyrr en á milli 1980 og 1990 að samstaða myndast um að kredit sé vara og verð vörunnar, vextir og pjónustugjöld ákvarðist á markaði. Tímabilið eftir 1980 einkennist af pví að menn hafa meiri og meiri efasemdir um gagnsemi pólitískra inngripa varðandi upphæðir, lánstíma, notkun fjárins o.s.frv. Til dæmis var á tímabilinu reynd aðhaldsstefna sem nefnd var kartoffelkuren ${ }^{6}$. Hluti af peirri stefnu var að stytta lánstíma og að lán skyldu greidd upp. Pví fylgdi mikil verðlækkun eigna og ný ríkisstjórn breytti um stefnu sem hvatti til lántöku. •að var kallað finansiel kickstart (Rasmussen, ofl. 2011).

\subsection{Evrópu- og hlutafélagavæđing eftir 1989.}

Lögin frá 1989 marka tímamót pví að með peim er endanlega lokað fyrir að stofnuð séu ný samábyrgðarfélög um RK-lán. Miklar sameiningar eiga sér stað. Sameiningarferli var að nokkru leyti hafið upp úr 1965. Með lögum er ákveðið að ný RK-félög skuli vera hlutafélög. Í 25 ára afmælisriti Realkreditrådet er hlutafélagavæðing gömlu samábyrgðarfélaganna rædd.

\footnotetext{
${ }^{4}$ Eftirlitsnefnd pess tíma.

${ }^{5}$ Pegar maður sér útkomuna úr vinnu matsmanna verður maður að segja að hún hjálpar ekki mikið.

${ }^{6}$ Kartöflukúrinn.
} 
Par er pví velt upp hvort RK-félög verði hugsanlega eins og hver önnur fyrirtæki (Realkreditrådet 1997).

Pað má segja að árið 2015 séu á markaðnum tvær meginblokkir. Realkreditforeningen og Realkreditrådet eru samtök stærstu aðila á markaðnum. Meðlimir Realkreditrådet eru fjögur hlutafélög, BRFkredit A/S, DLR Kredit A/S, Nykredit Realkreditaktiselskab og Totalkredit A/S. Realkreditforeningen hefur prjá meðlimi, Realkredit Danmark A/S, Nordea Kredit Realkreditaktieselskab og LR Realkredit A/S (sem sérhæfir sig ílánum til landbúnaðar og lánar ekki einstaklingum). Bankar hafa á seinni árum orðið tengdari RK-starfseminni. T.d. sameinuðust BRFkredit A/S og Jyske-bank árið 2014. Petta eru allt hlutafélög sem mörg eiga rætur í eldri samvinnu-/samábyrgðarfélögum. Ljóst er að danska RK-kerfið á sér djúpar rætur í viðskiptahefðum sem ekki er auðvelt að flytja úr landi. Kjarninn í hugmyndinni er að jafnvægi sé í útlánum og skuldabréfaútgáfu (balance-princippet, match-funding). Tæknilega hefur jafnvægisreglan próast í tímans rás. Árið 2007 pótti tímabært að setja formlega fram tvær útfærslur af reglunni, det specifikke balanceprincip og det overordnede balanceprincip. Раð fyrra er formleg framsetning á hefðbundinni danskri RK-jafnvægisreglu, pað síðara er nýtískulegri útgáfa sem er undir áhrifum af Basel-II reglum um fjármálafyrirtæki. M.a. eru sett skilyðri um að laust fé skuli vera 30 daga greiðsluflæði. RK fyrirtækin eru frábrugðin öðrum fjármálastofnunum í peim skilningi að pau taka ekki við innlánum og ákvarða ekki vexti. Í töflum 2 og 3 eru sýnd nokkur tímamótaatvik í próun RK-starfseminnar.

Í 200 ára sögu RK-kerfisins hefur pað aldrei gerst að fjárfestir hafi ekki fengið sitt. Slík saga er til pess fallin að skapa traust. Peir lántakar sem skulda RK-lán losna ekki við pá skuld pó að peir fari í gjaldprot og veðið dugi ekki fyrir skuldinni. Á fundum með Realkreditforeningen og Realkreditrådet kom fram að kröfuhafar miðuðu stundum við 20 ár frá gjaldproti. Vel væri pó hægt að viðhalda kröfu lengur. Í Danmörku er sagt að pegar einstaklingur lendir í greiðsluproti get uppboðsferli hafist eftir 6 mánuði en pessi tími geti verið 7 ár í Frakklandi (Haldrup, 2014). Petta skýri að nauðungaruppboð og gjaldprot séu ófýsilegur kostur fyrir Dani (Haldrup, 2014). Campbell (2013) rekur ýmis atriði varðandi veðlán og húsnæðiskaup í ýmsum löndum. Greining hans leiðir í ljós að grundvallarpáttur í flestum löndum og flestum ríkjum Bandaríkjanna (Kalifornía undantekning) er að skuld fylgir lántaka pó svo að hann hafi purft að ganga út úr húsi með neikvætt eigið fé. Hann kallar pau ríki Bandaríkjanna par sem gengið er að öðrum eignum lántaka en húsinu „recourse states"7. Campbell telur að í endurkröfuréttarfylkjunum gangi kröfuhafar í Bandaríkjunum hægar fram í innheimtu en almennt í Evrópuríkjum. Danir hafa hefð fyrir harðri framgöngu í innheimtu við gjaldprot (Haldrup, 2014).

\footnotetext{
${ }^{7}$ Endurkröfuréttarfylkin.
} 
Tafla 2. Nokkrir punktar úr próun RK-kerfisins.

\begin{tabular}{|c|c|}
\hline $1797-1850$ & $\begin{array}{c}\text { Félagasamtök samábyrgjast lán til endurreisnar eftir stórbruna í } \\
\text { Kaupmannahöfn. Starfsemin er bundin við Kaupmannahöfn }\end{array}$ \\
\hline $1850-1950$ & $\begin{array}{c}\text { Mörg RK/HT félög verða til og starfa í allri Danmörku. } \\
\text { Samábyrgðarkerfi ríkjandi. Starfsemin hólfuð í svæði og } \\
\text { atvinnugreinar }\end{array}$ \\
\hline $1950-1970$ & $\begin{array}{c}\text { RK/HT lán pykja ekki duga. Ríkið grípur inn ía ýmsa vegu, t.d. } \\
\text { lánshlutföll, lánstíma, viðbótarlán. Ríkið reynir að sleppa út af } \\
\text { markaði með pví að stuðla að stofnun sjálfseignarsjóða. }\end{array}$ \\
\hline $1970-1989$ & $\begin{array}{c}\text { Miklar sameiningar. Ríkið notar enn reglur um RK-lán sem } \\
\text { hagstjórnartæki. „Kartoffelkuren” kveður á um stuttan lánstíma og } \\
\text { hraða niðurgreiðslu. }\end{array}$ \\
\hline $1989-2015$ & $\begin{array}{c}\text { Hlutafélagavæðing RK-fyrirtækja. Síðasta stóra hagstjórnarátak } \\
\text { ríkisins, ,kickstart’'-1993. Slaknar enn á jafnvægisreglunni sem er } \\
\text { formlega tvískipt 2007. Nýjar fjármálaafurðir koma fram. Tengsl } \\
\text { við banka aukast. Reglur Evrópusambandsins fá aukið vægi. }\end{array}$ \\
\hline
\end{tabular}

Tafla 3. Nokkur atvik og lagasetningar úr fjármálaumhverfi Danmerkur 1795-2015.

\begin{tabular}{|c|c|}
\hline 1795-1849 & $\begin{array}{l}\text { Bruni í Kaupmannahöfn 1795. RK-félögum leyft að bjóða út skuldabréf til endurreisnar í } \\
\text { borginni. } \\
\text { Nationalbanken stofnaður 1818, fyrirrennari seðlabanka. } \\
\text { Ýmsir sparisjóðir stofnaðir. Taka fyrst við innlánum og kaupa ríkisskuldabréf. Veita síðar } \\
\text { útlán. }\end{array}$ \\
\hline 1849-1914 & $\begin{array}{l}\text { Ný stjórnarskrá 1849. Félagafrelsi opnar á fjölda RK-félaga um alla Danmörku. } \\
\text { Den Danske Landmansbank Hypothek og Vexelbank stofnaður 1871. Viðskiptabankar ná } \\
\text { fótfestu } \\
\text { HT-félagasamtök hefja lán á veðrétti neðar en RK-félög } 1895 .\end{array}$ \\
\hline 1914-1945 & $\begin{array}{l}\text { Heimsstyrjöld 1914-1918. Verðbólga og gengi gjaldmiðla riðlast. Tvímyntar skuldabréf } \\
\text { bönnuð 1923. Lagabætur. Lög um HT-félög. Kreppa og útlánatöp upp úr 1930. Danmörk } \\
\text { hernumin. }\end{array}$ \\
\hline $1945-1970$ & $\begin{array}{l}\text { Ýmis afskipti stjórnvalda. Skattabreytingar og sjálfseignar-RK sjóðir settir á stofn að } \\
\text { frumkvæði ríkisins. Eigendastaða meðlima í RK-félögum dofnar. Priggja laga fjármögnun } \\
\text { komið á fót } 1958 .\end{array}$ \\
\hline 1970-1989 & $\begin{array}{l}\text { Driggja laga kerfi afnumið 1970. Miklar sameiningar RK-félaga. Realkreditrådet stofnað } 1972 . \\
\text { Í fyrstu sem hagsmunasamtök og eftirlitssamtök. Jafnvægisreglan mýkist. Sveiflur í verðbólgu } \\
\text { og vöxtum (10-25\%). Ýmsar stjórnvaldsaðgerðir, t.d. kartoffelkuren. }\end{array}$ \\
\hline $1989-2000$ & $\begin{array}{l}\text { Evrópu- og hlutafélagavæðing. Ný lög } 1989 \text { eftir } 12 \text { ára aðlögunarferli við Evrópureglu frá } \\
\text { 1977. RK-félög sameinast. Enn teygt á jafnvægisreglunni. Nýjar fjármálaafurðir koma fram. }\end{array}$ \\
\hline $2000-2015$ & $\begin{array}{l}\text { Öll RK-lána starfsemi á hendi hlutafélaga. Enn frekari aðlögun að Evrópureglum með lögum } \\
\text { frá } 2003 \text { og 2006. Jafnvægisreglunni formlega tvískipt í hefðbundna útgáfu og Basel-II útgáfu. } \\
\text { Enn fleiri fjármálaafurðir koma fram, svo sem afborgunarlaus lán. Alpjóðleg } \\
\text { skuldabréfakreppa 2008. Stjórnvaldsviðbrögð með markaðsinngripi } 2008 \text { og lögum um } \\
\text { vaxtabreytingar við endurfjármögnun } 2014 \text {. }\end{array}$ \\
\hline
\end{tabular}

\section{Fjármálaafurðir og uppgreiðslur}

Í upphafi 19. aldar var eins og nú að menn sem höfðu nýjungar á prjónunum leituðu eftir stuðningi ríksins við verkefnið. RK-félögin voru par engin undantekning og tókst að ná pví fram að fjármagnstekjuskattur af RK-skuldabréfum og stimpilgjald var fellt niður. Petta gilti um takmarkaða lánsupphæð og einungis ef um nýbyggingu á brunarústum væri að ræða. Hér var pví um niðurgreiðslu á vöxtum/fjármagnskostnaði að ræða. Раð að RKskuldabréfaútgáfan væri undanpegin stimpilgjöldum var e.t.v. ekki beinn ríkisstuðningur pví að RK-fyrirtækin miðla lánum og lántakinn borgar stimpilgjöld af peim lánum sem hann tekur og var pví í raun verið að koma í veg fyrir tvísköttun. Í upphafi 19. aldar var 
fjármagnstekjuskatturinn á pví formi að 0,25 prósentustig runnu til ríkisins. Ef hámarksvextir voru 4\% pá pýddi pað að fjárfestir fékk í mesta lagi 3,75\% vexti eftir skatt. Pessi skattur var aflagður fljótlega á 19. öld. Tímabilið frá 1945 og fram yfir 1980 einkennist af margpættum ríkisafskiptum par sem hið opinbera leitaðist við að stytta lánstíma, setja inn ákvæði um hvernig lánið væri notað, hverjir mættu fá lán o.s.frv. Einnig voru settir á stofn opinberir sjóðir sem höfðu afskipti af ýmsum fjárfestingum. Jafnframt einkenndist tímabilið af tíðum skattkerfisbreytingum.

Sá sem skuldar 30 ára fastvaxtalán og vill endurfjármagna á lægri vöxtum parf að taka á sig viðskiptakostnað, pjónustugjöld til fjármálastofnana og stimpilgjöld (og fleiri skatta) til ríkisins. Мeð tilkomu nýrra afurða á fjármálamarkaði má segja að markaðsaðilar víki sér undan skatti (stimpilgjaldi) með pví að skilgreina endurfjármögnun ekki sem nýtt lán. Meðal slíkra nýrra afurða eru svokölluð F-lán. F-lánin eru byggð á stuttum óuppgreiðanlegum skuldabréfum. Pegar líftími F-láns er á enda er endurfjármagnað, t.d. með nýju F-láni. F-lánin eru auðskilin og bera lægri vexti en 30 ára fastvaxtalán með uppgreiðslurétti. Petta gæti að hluta skýrt vinsældir F-lánanna og fleiri nýrra RK-afurða.

Eftir inngrip Evrópubandalagsins 2007 voru RK-fyrirtækin skyldug til að hafa sérstakar tryggingar gagnvart yfirveðsettum eignum. Vörnin felst í að gefin eru út sértryggð skuldabréf, særlig dækkede obligationer(SDO) (enska: Covered Bonds). Hugmyndin er að pegar verð eigna fellur pá séu pessi bréf trygging fyrir pví að fjárfestir fái sitt komi til greiðslufalls. Sérstök RKútgáfa af SDO, SDRO særlig dækkede real obligationer, sem einungis RK-félög mega gefa út hefur einnig verið sett á markað. Pessi tegund fjármögnunar er hins vegar frávik frá hinni hefðbundnu jafnvægisreglu RK-lána. Hlutur SDO og SDRO hefur aukist mikið frá 2007 (Realkreditrådet, 2012). Árið 2013 voru pau orðin meirihluti útistandandi skuldabréfa RKfyrirtækja. Pau njóta ákveðins forgangs við hugsanlegt gjaldprot fjármálastofnana og eru pví eftirsótt af fjárfestum sem sérlega örugg eign. Ávöxtunarkrafa peirra er pví lág og njóta lánpegar pess í ákveðnum mæli.

Aðalafurðir RK-stofnana hafa lengi verið fastvaxtalán til langs tíma með uppgreiðslurétti. Uppgreiðslunni er miðlað til skuldabréfaeigenda í formi óreglulegra afborgana. Í dag er notast við reglu sem kölluð er matematisk udtrækning8. Sú regla ákvarðar hlutfall óreglulegrar afborgunar. Eftir 1990 og sérstaklega eftir 2000 jókst fjölbreytni lána. Mest umtöluð eru lán sem kölluð eru avdragsfri, p.e. afborgunarlaus lán. Frá árinu 2003 hafa verið í boði lán sem eru afborgunarlaus í allt að 10 ár.

Hin hefðbundnu 30 ára fastvaxtalán hafa verið á undanhaldi frá árinu 1996. Ýmis önnur lán með breytilegum vöxtum, sem oftast hafa verið lægri en föstu 30 ára vextirnir, hafa orðið ráđandi. Lánaflokkarnir F1, F3 o.s.frv. lýsa pví að vextir séu fastir í 1 og 3 ár o.s.frv. Skuldabréf eru seld á uppboði til pess að para pessi vaxtatímabil. Pessi lán eru óuppgreiðanleg á vaxtatímabilinu og pví má segja að RK-félögin hafi komið vissum böndum á uppgreiðsluáhættuna. Рað má segja að um vissa sveigju sé að ræða á gömlu jafnvægisreglunni pví að boðin eru lán par sem vöxtum er breytt oftar en einu sinni á ári pó svo að skuldabréfið að baki láninu sé til eins árs, t.d. getur verið um að ræða einhvers konar blöndu af F1 og F2 láni með mörgum vaxtadögum á tveggja ára tímabili'. Í töflu 4 eru taldar upp nokkrar útfærslur. Einhver RK-félög reyndu á árunum 1976-1985 að markaðssetja lán með breytilegum vöxtum en pau lán náđu ekki mikilli útbreiðslu (Astrup Jensen, 2013). Á árunum eftir 2000

\footnotetext{
8 Stærðfræðilegur útdráttur.

${ }^{9}$ Petta samræmist hins vegar nýrri útgáfu af jafnvægisreglunni (det overordnede balance-prinsip), sem er undir áhrifum frá Basel-II reglum.
} 
hafa RK-félögin einnig gefið út skuldabréf par sem vextirnir miðast við einhverja ytri vexti, t.d. stýrivexti, CIBOR, EURIBOR o.s.frv.

Eftir tilkomu evrunnar gefa RK-félögin út skuldabréf í evrum og dönskum krónum og geta lántakendur valið um gjaldmiðil.

Tafla 4. Ýmsar lánategundir RK-fyrirtækja.

\begin{tabular}{|cc|}
\hline F1, F3, F5 lán & Lán til 30 ára með föstum vöxtum í 1, 3 eða 5 ár \\
Fastvaxtalán & Lán til 10, 20, 30 ára fastir vextir út lánstímann \\
Afborgunarlaus & Engar afborganir í tiltekinn tíma (mest 10 ár) \\
\hline
\end{tabular}

Í upphafi voru lán uppsegjanleg (opsigelig) bæði að hálfu lánpega og lánveitenda. Á árunum eftir 1850 pegar lánpegastýrð félög hófu útgáfu skuldabréfa urðu ráðandi bréf sem voru uppsegjanleg af hálfu lánpega en ekki lánveitenda ${ }^{10}$. Раð er pví löng hefð fyrir uppgreiðanlegum RK-lánum. Í tímans rás hefur orða- og hugtakanotkun próast, samanber forgangur/veðréttur. Til dæmis er í dag sagt á íslensku að lán sé uppgreiðanlegt ef lánpegi má greiða upp lánið hvenær sem er. Á dönsku er orðið konverterbar notað. Рað að lánveitandi geti sagt upp lánasamningi er á nútíma íslensku kallað að lánveitandi geti gjaldfellt lánið. Eftir 1860 má segja að möguleiki lánveitanda til að gjaldfella RK-lán einhliða sé úr sögunni. Lán eru einungis gjaldfelld ef lántaki stendur ekki við sinn hluta samnings. Á 19. öld var pað líklega ekki til að varast vaxtalækkanir, heldur til að verjast einokunarverðlagningu tiltekinna skuldabréfa. Í 200 ára sögu RK hafa uppgreiðslur komið í nokkrum bylgjum (Møller \& Nielsen, 1997). Hin venjulega leið til uppgreiðslu láns var að fara út á markaðinn og kaupa skuldabréfið til baka. Ef veltan, p.e. framboðið af pví skuldabréfi sem skuldarinn vill kaupa, er lítið, pá má hugsa sér að seljandinn geti krafist yfirverðs. Útgáfa á óuppgreiðanlegum skuldabréfum hélt pó áfram og pessi einokunarverðlagning kom úr fylgsni sínu. Til dæmis var gengi skuldabréfa RK-félagsins, Dansk Landbrugs Realkreditfond, langt yfir 100 og pví mjög dýrt fyrir bændur að kaupa skuldabréfin til baka. Petta pótti herða svo rækilega að landbúnaði að ríkisstjórnin greip inn í á pann hátt að skuldurum bauðst að losna undan skuldinni með pví að kaupa ríkisskuldabréf sem var pannig að afborganir af ríkisskuldabréfinu greiddu afborganir af upphaflega skuldabréfinu Møller \& Nielsen (1997, bls.136). Раð má segja að parna hafi jafnvægisreglan verið brotin, pví að ríkisskuldabréf var á móti RK-skuldabréfi.

Á 19. öld voru lengst af $4 \%$ lögbundnir vextir á skuldabréfum. Pegar gengi slíkra bréfa fór yfir 100 gerðu menn sér grein fyrir að markaðsvextir voru lægri og gáfu út bréf með 3,5\% vöxtum og jafnvel 3,0\%. Árið 1915 var prýstingur á vexti upp á við og sótti pá Creditkassen i Østifterne um að fá að gefa út bréf með $5 \%$ vöxtum. Peirri beiðni var neitað og brást félagið við með pví að hafa bréfið óuppgreiðanlegt í 10 ár. Pannig hækkuðu peir verðið á bréfinu (Møller \& Nielsen, 1997). Ljóst er pví að menn hafa snemma áttað sig á að valið um uppgreiðanleika er ekki ókeypis. Í töflu 2 í grein eftir Frankel, Gyntelberg, Kjeldsen \& Persson (2004) sýna höfundar tengsl vaxta og höfuðstóls skuldar við uppgreiðsluhegðun. Eins og vænta má eru stórskuldarar líklegri til að kaupa til baka skuldabréf sín og skuldabréf með háum vöxtum eru frekar greidd upp. Til dæmis höfðu á tímabilinu 1997-2002 45\% af peim sem skulduðu meira en 3 milljónir DKK á 10\% vöxtum eða hærri greitt upp sín lán, 11\% af peim sem skulduðu minna en 200.000 DKK á 10\% vöxtum og einungis 3\% af peim sem skulduðu 200.000 á 6\% vöxtum. Frankel, Gyntelberg, Kjeldsen \& Persson (2004) rekja og vísa til rannsókna sem benda til pess að lánpegar noti uppgreiðsluréttinn ekki endilega á

${ }^{10}$ Call option for debitor. 
hagkvæmasta máta. Рað er eflaust bæði viðskiptakostnaður og fáfræði sem gerir að lánpegar endurfjármagna ekki uppgreiðanleg skuldabréf pegar vextir lækka. Sögulega hafa peir sem fjárfest hafa í RK-skuldabréfum purft að nota flókin tölfræðileg líkön til að spá fyrir um uppgreiðsluhegðun lántaka. Petta er ekkert sérdanskt vandamál. Demarzo \& Duffie (1999) rekja aðferðir um hvernig megi verjast og verðleggja uppgreiðsluáhættu.

Á seinni árum má segja að hlutfallslegt vægi uppgreiðslu hafi minnkað pví að gömlu 30 ára fastvaxtalánin hafa að miklu leyti verið greidd upp með lánum á breytilegum vöxtum. Meiri hluti útistandandi lána er nú endurfjármagnaður reglulega með skammtímaskuldabréfum (Realkreditrådet, 2012).

Umdeild stjórnvaldsaðgerð var skattalagabreyting árið 1993, par sem lántakendum var boðið að fá að halda skattaafslætti vegna verðhækkunar á skuldabréfum pó svo að peir greiddu upp lánið. Petta stjórnvaldsinngrip gerði pað að verkum að mun fleiri nýttu sér uppgreiðslurétt á skuldabréfum með 18-20\% vöxtum og eigendur skuldabréfa fengu óvænt högg. Hugmyndin með pessari aðgerð var að reyna að aftra frekari verðlækkun fasteigna og örva hagkerfið (finansiel kickstart). Møller \& Nielsen (1997) benda á að stjórnvaldsaðgerðir af pessari gerð séu ekki gagnlegar pví að markaðurinn læri af pessu og bæti áhættupóknun við verð skuldabréfa í framtíðinni. Skattalagabreytingar hafa áhrif á hegðun aðila á markaði. Pað getur t.d. haft áhrif á hvort lántakar fá peninga beint í hendur (kontantlån) eða skuldabréf sem peir purfa síðan að selja á markaði (obligationslån). Skattaleg meðferð peningalána og skuldabréfalána er ólík. Á vissum tímabilum hefur annað pótt betra en hitt. Núgildandi reglur eru að gengishagnaður við uppgjör peningaláns er skattskyldur, en gengishagnaður við uppgjör skuldabréfaláns ekki.

Раð má segja að uppgreiðanleg skuldabréf hafi verið ráðandi í sögu RK-skuldabréfa. Рað hafa einnig verið í boði óuppgreiðanleg skuldabréf. Nánast öll verðtryggðu skuldabréfin sem gefin voru út upp úr 1980 voru óuppgreiðanleg. Verðtryggð RK-lán voru í nokkrum flokkum (I, AI, IE, IS, SI, IJ) og voru notuð til að fjármagna tiltekna málaflokka. T.d. var flokkurinn IJ (indeks-jordbrug) helgaður landbúnaði og par mátti ef viss skilyrði voru uppfyllt greiða upp skuldabréfið. Astrup Jensen (2013) rekur eðli pessara verðtryggðu dönsku lána. Astrup Jensen (2013, bls. 232) segir að Danir séu á ýmsan hátt eftirbátar annarra í próun verðtryggðra samninga og nefnir sem dæmi að Danir hafi ekki gefið út verðtryggð ríkisskuldabréf fyrr en 2012. Hann vísar í Deacon, Derry \& Mirfendereski (2004) sem gott yfirlitsverk um notkun verðtryggingar í heiminum. Рað má segja að verðtryggði IS-skuldabréfaflokkurinn (IS=indeksstøttet byggeri) sé óbeint hluti af opinberum skuldum Danmerkur (Astrup Jensen, 2013).

\section{Eignarhugtök og verðmat}

Pegar lána á ákveðið hlutfall t.d. 80\% af virði eignar pá parf að liggja fyrir mat á eigninni. Skattayfirvöld meta eignir með sínum hætti og hvert RK-félag framkvæmir sitt eigið mat. Samkeppniseftirlitið bannar pessum aðilum samvinnu við matið. Рað er pví ekki augljóst hvað 80\% pýðir. Sumir vilja nota kaupverðið sem hið raunverulega mat, t.d. pannig að ef einhver framvísar skilyrtum kaupsamningi pá sé hann vísbending um mat.

Í upphafi voru RK-lán veitt til handhafa lóðar. Fasteign var jarðnæði og allt sem á pví stóð. Lóðarhafi gat sett upp fjós, verksmiðju, íbúðarhúsnæði eða hvað sem honum póknaðist á landinu. Árið 1966 var ákveðið að hugtakið eignaríbúð (ejerlejlighed) skyldi skilgreint í Danmörku. Rökin voru einhvern veginn á pá leið að fyrst hægt væri að skilgreina margar fasteignir hlið við hlið á gamalli lóð pá væri alveg eins hægt að skilgreina fasteignir sem staflað væri upp lóðrétt. Eignarréttur í fjölbýlishúsi er pinglýst skráð eign á sama hátt og einbýlishús 
og eigandinn ræður öllu innan dyra, p.e. má breyta herbergjaskipan og leigja út húsnæðið. Húspak, stigar, bílastæði, gluggar og pað sem er utanhúss er sameign, p.e. pað er húsfélag (ejerforening) sem ber rekstrarskyldur við fasteignina. Oft hefur pað félag einhvers konar formlega kröfu (pantebrev) á íbúðareigandann til að tryggja greiðslur til samrekstursins. Greiðsluskylda og atkvæðisréttur í pessum félögum er hlutfallslegur, í hlutfalli við fermetra, p.e. að stærri íbúð hefur pyngra vægi en lítil. Húsfélagið getur sett íbúð á nauðungaruppboð ef íbúðareigandi stendur ekki í skilum við félagið. Húsfélagið tekur ekki sjálft RK-lán en íbúðareigandinn getur fjármagnað sig að hluta með RK-lánum.

Pessi lýsing á útfærslu á eignaríbúðarhugtakinu er ekki framandi í augum Íslendinga. Hún er pó fjarri pví að vera sjálfsögð. Í Svípjóð var eignaríbúðarhugtakið ópekkt par til 1. maí árið 2009. Fram að peim tíma höfðu Svíar notað pá skilgreiningu á fasteign að pað væri land með öllu sem á pví stendur.

Hugtakið andelslejlighed á við aðild að húsnæðisfélagi. Sá sem kaupir andelslejlighed kaupir staðfestingu á pví að hann eigi hlut í félagi, andelsforening, og hafi par með afnotarétt á íbúð. Рað er félagið sem ákveður alla hluti er varða íbúðina og meðlimirnir hafa atkvæðisrétt óháð stærð íbúðar. Félagið ákveður verð hlutarins, p.e. ekki íbúðarhafinn. Vel flest félög af pessari gerð eru með reglur um verðlagningu. Eignin sem andelslejlighed er í hefur oft verið fjármögnuð með RK-láni, en pað er félagið sem hefur tekið lánið en ekki íbúðarhafinn. ${ }^{11}$ Íbúðarhafinn getur ekki veðsett sinn hlut og fengið út á hann RK-lán. Íbúðarhafinn borgar húsaleigu sem félagið notar til reksturs eignarinar, afborganir af lánum (m.a. RK-lánum), o.s.frv. Efnahagsreikningur félagsins getur pví verið flókinn og mikið atriði að sá sem kaupir hlut(andel), setji sig inn í stöðu félagsins áður en hann kaupir sig inn. Félagið parf að sampykkja nýjan eiganda. Félagið getur til dæmis verið með reglur um að börn eða gæludýr skuli ekki búa í íbúðinni eða að íbúinn sé eldri en 50 ára.

Frá upphafi hafa verið ítarleg ákvæði um hversu mikið megi lána út á hverja fasteign. Ákvæðin hafa verið á pví formi að RK-stofnun megi lána allt að $60 \%$ af virði eignar. Í nýbyggingu liggur byggingarkostnaður fyrir og pví eðlileg viðmiðun. Í ýmsum tegundum atvinnuhúsnæðis eru upplýsingar um veltu aðgengilegar og nothæfar sem mat á virði húsnæðis. Í öðrum tilfellum er markaðsvirði óljóst og nauðsynlegt að leggja í sérstaka matsvinnu til að fá upplýsingar um virði eignar. Nú er pess krafist að ef eign er fjármögnuð með SDO (særligt dækkede obligationer) eða SDRO (særligt dækkede realkredit obligationer) pá megi lánshlutfall ekki vera hærra en 75\% og nauðsynlegt að meta íbúðarhús að minnsta kosti priðja hvert ár og atvinnuhúsnæði hvert ár.

\section{$5 \quad$ Próun verðbólgu og vaxta}

Fyrr á öldum var tæknilega erfitt að reikna út vexti og afborganir. Meðal tæknilegra úrlausna var að festa áletraða miða (coupon) á skuldabréfið par sem kveðið var á um greiðslu á tilteknum degi. Miðarnir voru síðan rifnir af og sendir í pósti. Önnur útfærsla var að númera skuldabréfin og hafa síðan einhvers konar happdrætti um hvaða bréf skyldi greitt upp. Líkindafræðin sá pannig um afborganirnar. ${ }^{12}$ Lengi vel á 19. öld voru hámarksvextir á RKskuldabréfum $4 \%$. Vextir höfðu pví lækkað úr $5 \%$ á miðri 18. öld en heimildir eru um að peir hafi verið 6,25\% fyrr. Pað hlutfall er líklega tengt gjaldmiðilskerfi par sem talan 16 er viðmið.

11 Nýlega hefur Nordea samstæðan boðið einstaklingum lán með RK-eiginleika til kaupa á andelslejlighed.

12 1989-2004 var í gildi á Íslandi svonefnt húsbréfakerfi með pessu fyrirkomulagi. 
Menn fengu 16 einingar að láni en áttu að borga til baka 17 einingar síðar (1/16=6,25\%). Til eru dæmi um að sótt hafi verið um heimild til að hafa hærri vexti en $4 \%$, t.d. $5 \%$, á skuldabréfum og pví hafi ýmist verið synjað eða sampykkt. Í upphafi 19. aldar voru einnig ýmiss konar gjaldmiðlar í notkun, málmpeningar og pappírspeningar. Hægt var að gera samninga í bæði málmi og pappír. Danir lentu illa í Napóleonsstríðunum (1803-1815) og verðbólga var vandamál á árunum fram að 1814. Danska ríkið reyndi að endurheimta lánstraust með eins konar eftir-á-verðtryggingu og lofa að standa við sínar raunskuldbindingar (Møller \& Nielsen, 1997, bls. 81).

Frá 1815 til 1914 var verðbólga í Danmörku og víðar óveruleg. Um pað bil helming tímabilsins var verðhjöðnun. Gengi skuldabréfa á 4\% vöxtum var oft yfir 100 pannig að prýstingur var á lækkun vaxta. Til dæmís pannig að bréf með 3,5\% og jafnvel 3,0\% vöxtum voru seld á markaðsgengi 100. Verðhjöðnun var nánast annað hvert ár, sem var ekkert sérdanskt fyrirbæri. Í töflu 1. hjá Bordo \& Filardo (2005, bls.28) sést að langtímaverðbólga á 19. öld var nánast engin. Vísbendingu um próun hrávöruverðs á 19. öld má t.d. lesa í Sögu skútualdarinnar eftir Gils Guðmundsson (1946) en par segir að verð á tunnu af hákarlalýsi hafi verið 23 ríkisdalir árið 1820 og 24 ríkisdalir árið 1872. Hæst fer pað í 29 ríkisdali árið 1864 og er lægst 16 ríksdalir árið 1828. Verð á lýsi er skráð í krónum 1877 og virðist frekar vera á niðurleið fram að heimsstyrjöldinni fyrri 1914. Í mörgum löndum hækkaði verðlag nánast ekki neitt í 100 ár fram til 1914. Verðbreytingar milli ára voru pó oft miklar. Til dæmis lækkar verð í London um 20\% frá 1820 til 1914 en staðalfrávik breytinga milli ára er 5\% og verðbólga er mest $17 \%$ og verðhjöðnun er mest 17\%. Svipað gildir um önnur svæði í Evrópu (Bordo \& Filardo, 2005; Fisher, 1930).

Fyrri heimsstyrjöldinni fylgdu verðhækkanir sem að miklu leyti gengu til baka á árunum 1918-1935. Eftir 1945 er verðhjöðnun nánast ópekkt og verðbólga nánast viðvarandi.

Nielsen \& Risager (2001) lýsa ávöxtun á dönskum verðbréfum á tímabilinu 1922-1999. Meðalávöxtun hlutabréfa er hærri en skuldabréfa, eins og á mörgum öðrum mörkuðum. Nafnávöxtun skuldabréfa er í 5-7 \% rétt eftir fyrri heimsstyrjöldina en dalar síðan. Á tímum verðbólgu og mikilla ríkisafskipta eftir 1945 er mikill breytileiki í ávöxtun skuldabréfa sem nær hámarki í kringum 1980. Lætur nærri að pá hafi Danir búið við 10\% raunvexti í 10 ár. Nafnávöxtun var pá um og yfir 20\%. Petta leiddi m.a. til pess að Danir settu sérstök lög um verðtryggingu 1982. Andersen \& Gyntelberg (1999) segja: Udgangspunktet var en situation med høj inflation (ca. 10 pct) og høje effektive obligationrenter (ca. 19 pct.). ${ }^{13}$

Raunvextir voru pví í kringum 10\% á um pað bil 10 ára tímabili. Svo hátt raunvaxtastig í langan tíma hefur lamandi áhrif á byggingariðnað og aðrar fjárfestingar. Í munnlegum samskiptum við einn af peim (Jens Lunde) sem vann við að próa verðtryggða samninga á pessum tíma kom fram að petta hafi að hluta verið pólítísk aðgerð sósíaldemókrata sem vildu stuðla að byggingu húsnæðis sem lágtekjufólk réði við. Danir hafa parna verið á svipaðri línu og Campbell \& Cocco (2003) sem álykta að framboð verðtryggðra lána auki velferð almennings, sérstaklega lágtekjufólks. Einn flokkur verðtryggðra skuldabréfa frá pessum tíma heitir IS. Par sem IS stendur fyrir „indeks-støttet-byggeri"14, p.e. einhvers konar styrkta byggingarstarfsemi.

${ }_{13}$ Útgangspunkturinn var staða með mikilli verðbólgu (u.p.b. 10\%) og hárri ávöxtunarkröfu skuldabréfa (u.p.b. 19\%).

${ }^{14}$ Vísitölustyrkt byggingarstarfsemi. 
Meðalraunávöxtun skuldabréfa í 80 ár, 1922-1999, sem Nielsen \& Risager (2001) skoða er um 4,5\%. Eftir aldamótin 2000 hafa vextir að mestu verið á niðurleið ef undanskilið er stutt tímabil á árunum 2005-2008.

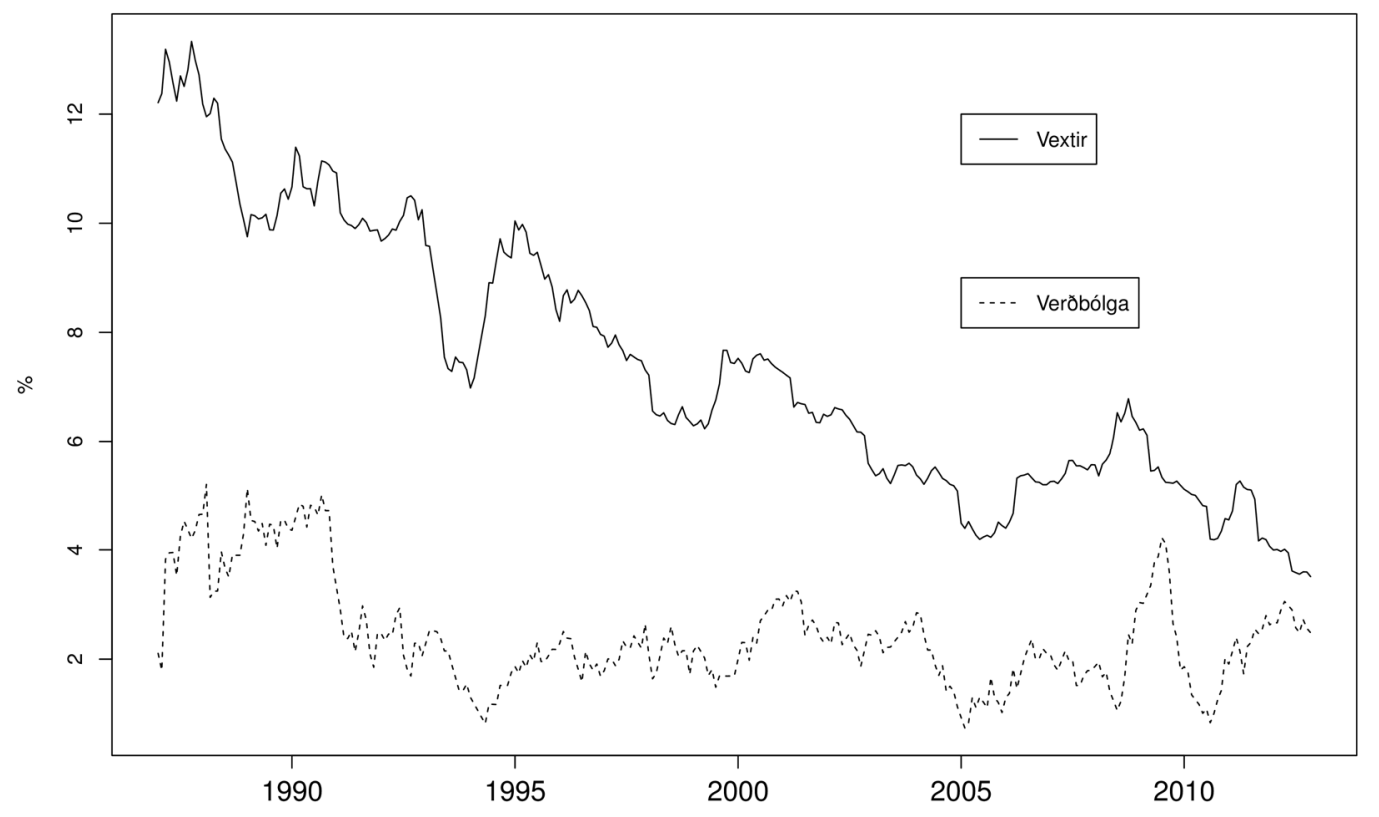

Mynd 1. Próun vaxta á 30 ára RK-lánum og árleg breyting á neysluverðsvísitölu. Byggt á tölum frá nationalbanken.dk.

Tímabilið eftir 2000 hefur einkennst af sögulega mjög lágum vöxtum, ekki einungis í Danmörku heldur einnig í flestum af stærstu gjaldmiðlum heims. Setningin „vextir í sögulegu lágmarki" hefur oft verið notuð til að lýsa ástandinu (Astrup Jensen, 2013). Petta lágvaxtatímabil hefur hugsanlega skert svigrúm RK-lána til að vera ódýrara en lán frá veðdeildum banka. Bankar kjósa ef til vill að bjóða út eigin skuldabréf og lána beint fremur en að kaupa hagstæð RK-skuldabréf og endurlána. Á mynd 1 er sýnd próun á árlegri breytingu neysluvísitölu og meðaltali 30 ára fastvaxta RK-lána samkvæmt útreikningum Seðlabanka Danmerkur (Nationalbanken). Vísitalan (Consumer Price Index), (cpi), er fengin frá Hagstofu Danmerkur (Danmarks statistik). Myndin sýnar lækkandi nafnvexti og raunvexti í 20 ár fram að 2005. Eftir 2005 er próun nafnvaxta enn að mestu niður á við en smákippir í verðbólgu. 


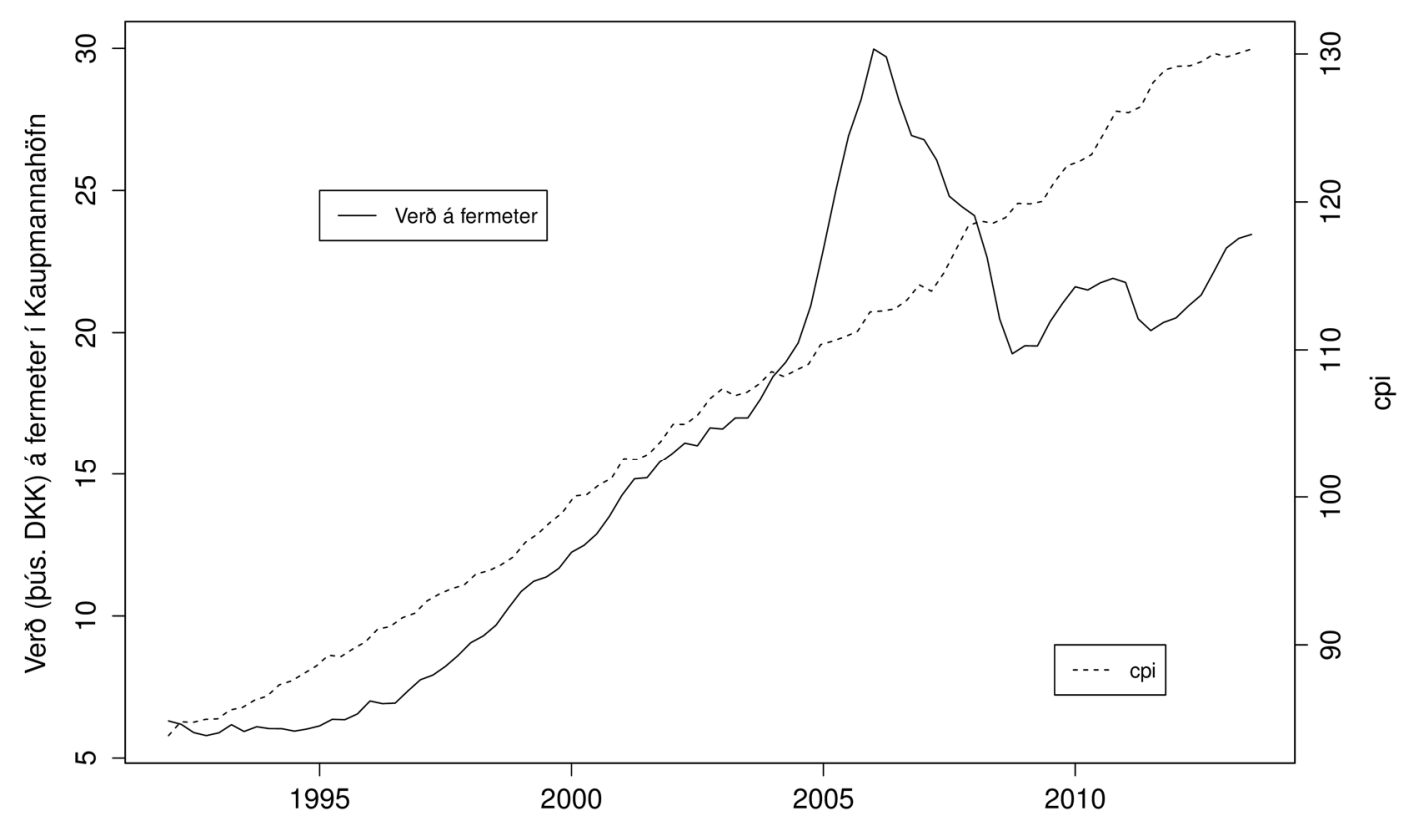

Mynd 2. Próun á fermetraverði í Kaupmannahöfn og nágrenni í púsundum danskra króna og neysluvöruverðsvísitölu. Gögn um verð á fermetra eru fengin hjá Realkreditrådet.

Mynd 2 sýnir próun fermetraverðs íbúðarhúsnæðis í Kaupmannahöfn og nágrenni og próun neysluvöruverðsvísitölu. Próunin er að miklu leyti í takt, en skrefstærð fermetraverðs er mun stærri, p.e. fermetraverðshækkunin er margföld vísitöluhækkun. Tímabilið 2004-2007 einkennist af mikilli verðbólu. Athugið að á mynd 2 eru tveir kvarðar. Fermetraverð fimm- til sexfaldast frá 1992 til 2008 en vísitala eykst einungis um 38\% til loka 2013. Pað er einnig athyglisvert að skoða verð á fermetra á föstu verðlagi. Á mynd 3 er sýnd próun verðs á fermetra á föstu verðlagi í Kaupmannahöfn og Reykjavík. Í toppi bólunnar 2006-2008 er raunverð í Kaupmannahöfn rúmlega prisvar og hálfu sinnum hærra en pað var 1992. Í Reykjavík rétt tvöfaldaðist raunverðið í bólunni. Verð fasteigna hefur hækkað í takt við lækkandi vexti og á vissum tímabilum gott betur. Vegna höfuðstólshækkunar er greiðsluskylda á fermetra pví vaxandi og mikil eiginfjármyndun hjá peim sem keyptu ódýrt. 


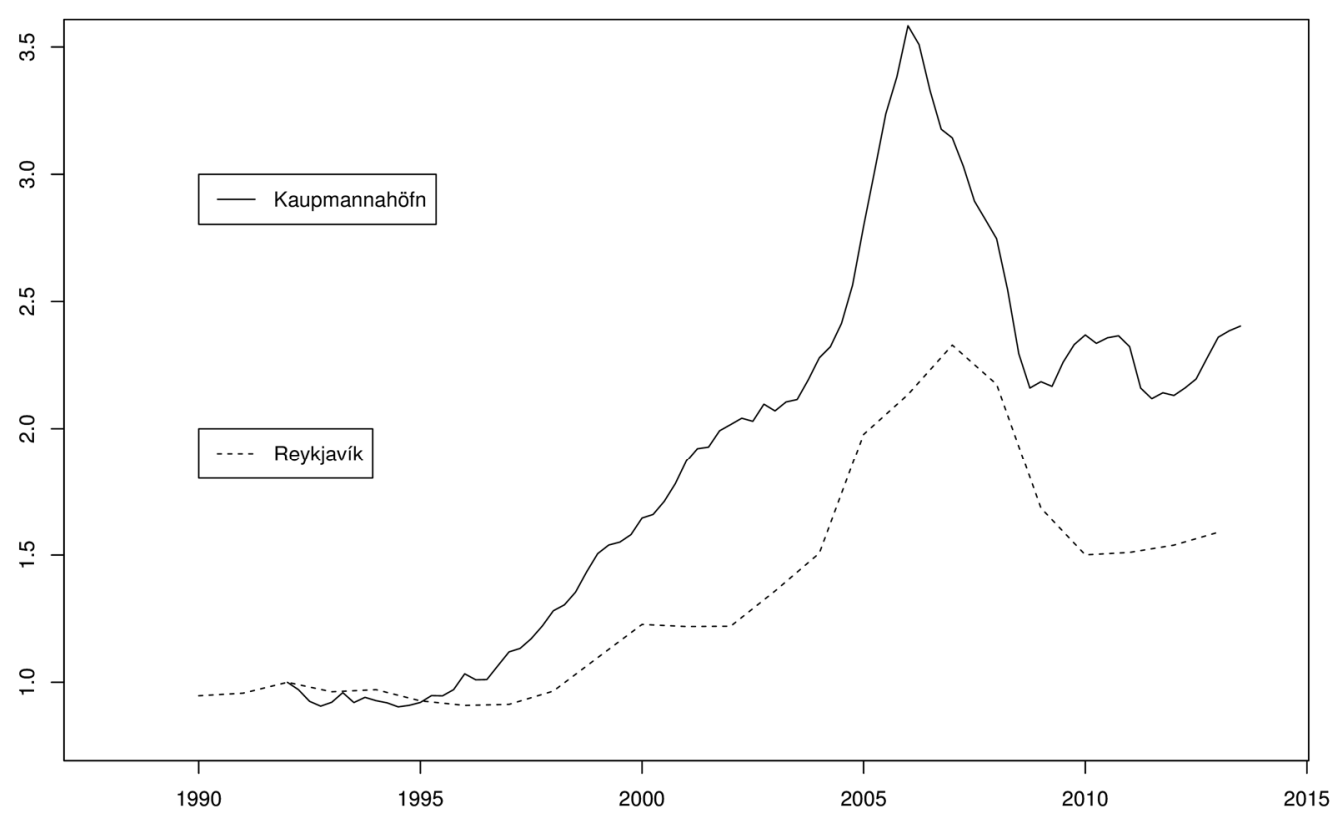

Mynd 3. Verð á fermetra í Kaupmannahöfn og nágrenni og Reykavík og nágrenni á föstu verðlagi 1992=1. Byggt á útreikningum höfundar og verðlagsgögnum frá hagstofum Danmerkur og Íslands

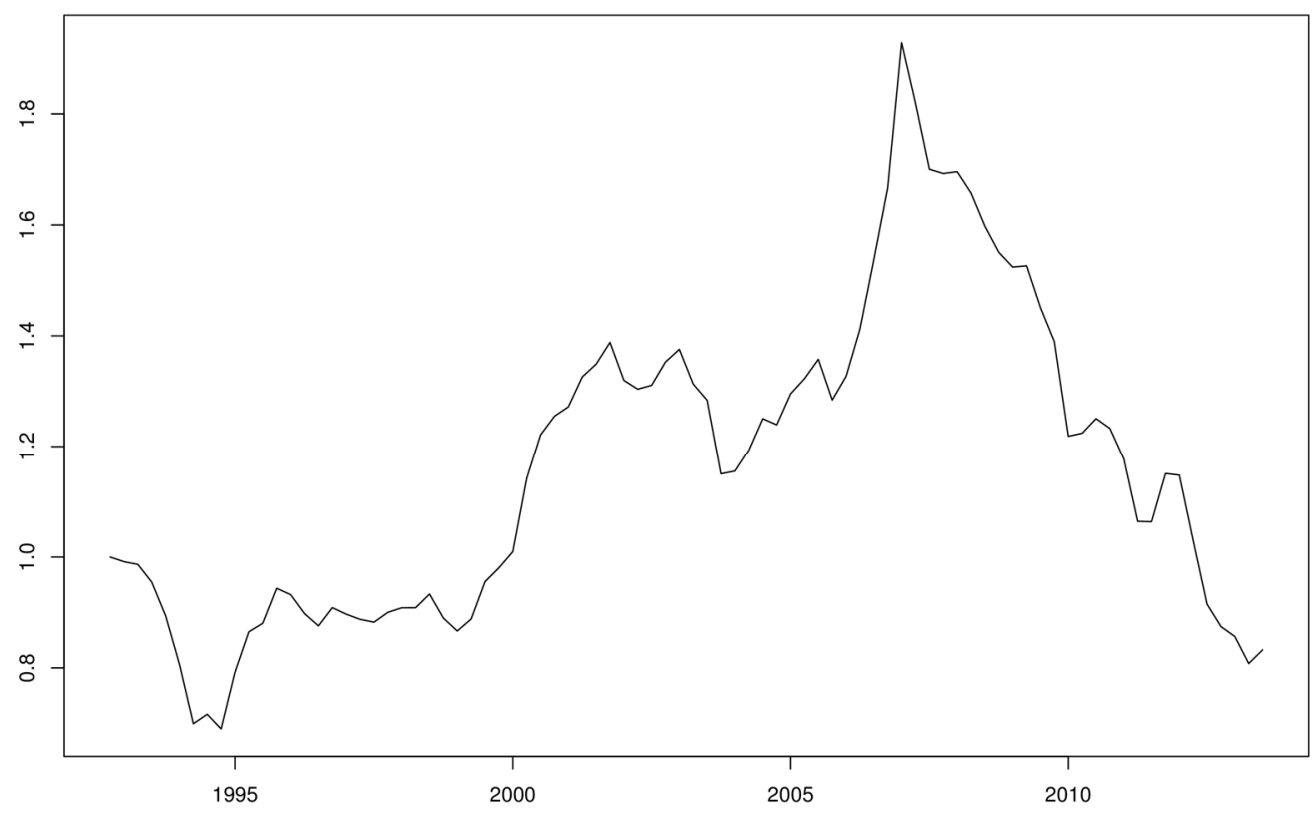

Mynd 4. Hlutfallslegur vaxtakostnaður á fermetra í Kaupmannahöfn og nágrenni á föstu verðlagi. Hér eru notaðir vextir af 30 ára fastvaxtalánum. Mánaðargögn frá Seðlabanka Danmerkur.

Á mynd 4 er próun vaxtakostnaðar á fermetra, miðað við 30 ára fastvaxtalán, í Kaupmannahöfn og nágrenni á föstu verðlagi sýnd. Рað virðist sem að í lok tímabilsins, 20132014, sé vaxtabyrði á fermetra svipuð og hún var í byrjun, árin 1992-1993. Рað má pó segja að 
staðan sé háskalegri árið 2013 en hún var 1992 pví að vextir geta varla lækkað mikið meira og svigrúmið í vaxtabreytingum virðist aðallega vera upp á við.

Ef aðgengileg væru íslensk gögn um sambærilega vexti yfir tímabilið mætti gera íslenska útgáfu af mynd 4. Vissa vísbendingu má fá með pví að sjá að í kringum 1990 var ávöxtunarkrafa af húsbréfum rúm $7 \% .{ }^{15}$ Íslendingar hafa pví pá verið að horfa á um pað bil $7 \%$ raunvexti sem áttu eftir að hækka. Í lok tímabilsins eru raunvextir á íbúðarlánum í kringum 4\%. Рað má pví áætla að vaxtabyrðin, p.e. margfeldi vaxta og höfuðstóls skuldar, á Íslandi sé svipuð í lok tímabilsins og í byrjun pess. Sama má segja um ástandið í Danmörku. Verðið hækkaði pað mikið í bólunni að danska vaxtabyrðin hækkaði mun meira en íslenska vaxtabyrðin á sama tímabili. Pessar myndir eru ekki réttvísandi fyrir greiðslubyrði pví að á tímabilinu eftir 2003 verða afborgunarlaus lán vinsæl í Danmörku. Í myndunum eru notaðir vextir á „hefðbundnum" 30 ára fastvaxtalánum. Eftir 1996 fer hlutur peirra á markaðnum minnkandi og óuppgreiðanleg lán með styttri fastvaxtatímabilum verða síðan algengari á 21. öldinni (Realkreditrådet, 2012). Pessar myndir samræmast pví að tilkoma afborgunarlausra lána og lækkandi vextir hafi að miklu leyti komið fram í hærra verði íbúðarhúsnæðis í Danmörku. Á tímabilinu 2010-2011 er minni hluti útistandandi skulda (undir 30\%, Realkreditrådet (2012), Haldrup(2014)) á fastvaxta 30 ára lánum með afborgunum. Lán með lægri breytilegum vöxtum og afborgunarlaus lán eru ráđandi.

Á pessu rúmlega 20 ára tímabili hefur pví raunverð fermetra í Kaupmannahöfn og nágrenni tvöfaldast en raunverð á fermetra í Reykjavík og nágrenni aðeins hækkað um 50\%. Á báðum svæðum má greina verðbólu. Verðbólan virðist vera stærri í Kaupmannhöfn og nágrenni. Freistandi er að álykta að stóran hluta pessa munar megi skýra með pví að greiðslubyrði af dönskum lánum hafi lést meira en á íslenskum lánum. Aðrir pættir gætu t.d. verið gæðabreytingar. Varasamt er að álykta um próun greiðslubyrði og samanburð milli landa. Laun og skattar hafa mikil áhrif pó að ætla mætti að greiðslubyrðin sé í grundvallar atriðum fall af margfeldi höfuðstóls og vaxta. Ýmis úrræði eru fyrir einstaklinga til að færa greiðslubyrði til á milli æviskeiða.

Í hinum vestræna heimi hefur meginpróunin verið sú að fasteignaverð hefur verið á uppleið og vextir á niðurleið. Nánari greining á peirri próun er utan sviðs pessarar greinar. раð er pó athyglivert að verðhækkun fasteigna í Kaupmannahöfn er umfram bæði pað sem skýra má með lægri nafnvöxtum og almennum verðlagshækkunum. Hér er Kaupmannahöfn valin sem samanburðargrundvöllur pví að Kaupmannahöfn er að miklu leyti einsleitur markaður. Í strjálbýlli hlutum Danmerkur og annarra landa er verðpróun margbreytilegri. Til dæmis eru illseljanlegar eignir í ýmsum minni bæjum.

\section{Samantekt og umræður}

\subsection{Staðani ídag}

RK-kerfið á sér langa sögu. Pað kerfi sem er ráðandi í ársbyrjun 2014 er í grundvallaratriðum frábrugðið pví upphaflega. Nú eru nokkur stór hlutafélög sem ráða markaðnum. Markmið peirra er að hámarka tekjur hluthafa. RK-félögin veita lán til fasteigna um alla Danmörku en eru ekki svæðis- eða atvinnugreinatengd eins og áður var. Veðrétturinn, forgangsröð kröfuhafa, er á allri eigninni en ekki háður pví hvers konar aðili veitir lánið, p.e. HT-fyrirtækin eru horfin.

${ }^{15}$ Húsnæðisstofnun ríkisins (með ríkisábyrgð) miðlaði skuldabréfalánum með svipuðum hætti og RK-fyrirtæki í Danmörku (húsbréfakerfið). 
Í upphafi voru RK-félögin samvinnu/samábyrgðarfélög, p.e. hugmyndin var að ef einn lántaki gæti ekki borgað pá myndu hinir hlaupa undir bagga. Síðan 1989 eru RK-félögin hlutafélög par sem hluthafar bera ábyrgð í samræmi við hlutafjáreign. Árið 2007 var að kröfu Evrópusambandsins bætt í lög um fjármálastofnanir að pau skyldu gefa út sérstök skuldabréf sem væru pannig að ef undirliggjandi veð færi undir tiltekið hlutfall ${ }^{16}$ af áætluðu virði pá pyrfti að leggja fram viðbótartryggingu. Pessi skuldabréf ganga í Danmörku undir heitunum SDO og SDRO (á ensku Covered Bonds og Junior Covered Bonds). RK-félögin tilkynntu að pau myndu ekki krefjast pessarar viðbótartryggingar af lánpegum (sem margir eru e.t.v. með neikvætt eigið fé), heldur myndi RK-félagið sjálft leggja pessa fjármuni fram. RK-félögin mega ekki taka stöðu í skuldabréfunum pannig að pau verða að fjármagna petta framlag á annan hátt. Рað fer pannig fram að RK-félagið tekur lán og bætir vaxtakostnaðnum af pví láni við árlega umsýslupóknun sem lánpegar borga félaginu. Pannig má segja að góðu skuldararnir borgi fyrir pá lélegu vegna hærri póknunar. Pví má að vissu leyti segja að samábyrgðin sé enn til staðar prátt fyrir hlutafélagavæðingu.

Í 25-ára afmælisriti Realkreditrådet (1997), koma fram áhyggjur af pví hvernig RKstarfseminni vegni í samkeppni við banka. Sérstaklega par sem sumir af meðlimum hagsmunasamtakanna eru nátengdir bönkum. Í dag er nánast öll RK-starfsemin nátengd bönkum en staðan á skuldabréfamörkuðum er sú að RK-bréf eru mjög stór hluti skuldabréfamarkaðarins. Samkvæmt töflu 4 hjá Meric \& Sorup (2010, bls 47) eru árið 2009 hlutafélögin Nykredit Realkredit A/S, Realkredit Danmark A/S, Nordea Realkreditaktieselskab og BRFKredit A/S með um 70-75\% af viðskiptum með skuldabréf (aðrir mælikvarðar 70\% af markaðsvirði, 67\% af veltu). Opinberir aðilar, Danmarks Nationalbank (ríkisskuldabréf) og KommuneKredit (sveitarfélög), með rúm 15\%.

\subsection{Markaðs- og tækniatriði}

Í dag eru RK-lán húskaupenda grunnurinn í lánamöguleikum einstaklinga. Ef einstaklingur á kost á RK-láni við fjármögnun pá tekur hann pað. Par eru hagstæðustu kjörin og reglan er nú og hefur lengst af verið að sá sem hefur aðgang að veði getur tekið RK-lán. Fjármálaráðgjöf gengur pví út á að hvetja fólk til að hafa sem mest af sínum skuldum í RK-formi. P.e. ef veðrými er til staðar pá sé best að borga niður önnur húsnæðislán, bílalán, námslán svo ekki sé talað um neyslu- og rekstrarlán. Sjá nánar á (http://www.laanogrealkredit.dk/Forbrugslaan.html). Mikilvægur páttur í fjármálaráðgjöf er um pað hvernig eigi að skuldbreyta og endurfjármagna. Uppgreiðanleg lán má borga upp á genginu 100 (á nafnverði). Vegna viðskiptakostnaðar er reyndin sú að uppgreiðslan svarar ekki kostnaði fyrr en skuldabréfið hefur gengið 102-105. Par sem skattaleg meðferð gengishagnaðar peningaláns og skuldabréfaláns er mismunandi getur reyndin verið að uppgreiðslan er ekki hagkvæm fyrir einstakling fyrr en gengið er 110 eða jafnvel hærra. Vaxtabreytingar hafa mikil áhrif á eigið fé skuldara. Verð fasteigna og gengi skuldabréfa próast í tíma og ekki endilega í takt. Ef lán að fjárhæð 100 er keypt aftur á genginu 80 pá hefur nafnverð bókfærðrar skuldar og eigin fjár í fasteign breyst. Skattaleg meðferð á pessum breytingum og hugsanlegri sölu eigna skiptir máli. Formúlur sem skýra pessi atriði má sjá til dæmis í Astrup Jensen (2013) og Rasmussen o.fl. (2011).

Tengingin að hvert lán sé fjármagnað með sérútgefnu skuldabréfi er enn ráđandi hugmynd en ekki eins fastskorðuð og áður. Gamla varan, 30 ára skuldabréf með föstum vöxtum og uppgreiðslurétti (á genginu 100), er ekki lengur aðalafurðin. Nú eru lán par sem

${ }^{16}$ T.d. ef áhvílandi lán er meira en 75\% af áætluðu söluvirði eignar. 
afborganir miðast við 30 ára afborganir, hugsanlega með afborgunarlausum tímabilum, sem fjármögnuð eru með runu af stuttum óuppgreiðanlegum skuldabréfum, ráðandi. Flokkar eins og t.d. F1, F2, fyrir eins eða tveggja ára óuppgreiðanleg bréf. Endurfjármögnun F-lána hefur vissan umsýslukostnað í för með sér sem parf að greiða árlega hjá peim sem eru með F1 lán og á fimm ára fresti hjá peim sem eru með F5 lán. Lánpegar purfa að kaupa sig út úr F-lánum, ef t.d. einhver vill greiða upp F5-lán eftir tvö ár. Pegar ný lán eru tekin parf að greiða stimpilgjöld. Endurfjármögnun á einu F-láni með öðru telst ekki nýtt lán, en uppgreiðsla á 30 ára fastvaxtaláni með nýju 30 ára fastvaxtaláni telst vera nýtt lán. Mörg lán frá RK-fyrirtækjum má borga upp hvenær sem er og endurfjármagna með öðru RK-láni. Vegna viðskiptakostnaðar eru uppgreiðslur og endurfjármögnun útbreiddari meðal peirra sem skulda háar upphæðir. Pað er pví ekki augljóst að greiðslubyrði danskra RK-lána sé meira fyrirsjáanleg en til dæmis íslenskra verðtryggðra lána. Kjörin á RK lánum ákvarðast að miklu leyti beint á markaði. Vextir RK-lána eru ekki samningsatriði, heldur miðla RK-fyrirtækin skuldabréfavöxtum beint til lántaka. Pau taka póknun (bidrag) fyrir að stjórna lánunum. Póknuninni er breytt pegar purfa pykir og er mismikil eftir pví um hvers konar lán er að ræða. Póknunin er hæst fyrir F1 lán.

Tilkoma SDO og SDRO skuldbréfanna á að tryggja fjárfestum aukið öryggi við hugsanlegt gjaldprot RK-fyrirtækis. Peir sem skulda RK-lán geta farið út á fjármagnsmarkaðinn og keypt skuldabréf sín til baka. Efasemdarmenn um RK-hugmyndina hafa dregið upp pá sviðsmynd að ef RK-félag standi illa, pá sé gengi skuldabréfa peirra hugsanlega lágt, skuldarar geti pá keypt pau á undirverði og gert upp skuldir sínar pannig. Fjárfestar fengju pannig of lítið til baka. Við gjaldprot banka er sá kostur ekki í boði, p.e. að geta keypt sparisjóðsbækur með háum innistæðum (hærri en innistæðutryggingin) og borgað síðan skuldir sínar við protabúið með peim sparisjóðsbókum. Viss tegund SDO skuldabréfa útgefnum af bönkum gefur skuldabréfaeiganda forgang umfram innistæður pess sem skuldar bönkunum. Ítarlega umfjöllun um lagalega stöðu fjárfesta í Danmörku við gjaldprot fjármálastofnunar má m.a. sjá hjá Pedersen (2010).

\subsection{Hvers vegna aðeins í Danmörku?}

Pað er athyglisvert að RK-hugmyndin hefur ekki náð fótfestu utan Danmerkur ${ }^{17}$. Hugsanleg skýring er að félagafrelsið 1849 hafi gefið RK-starfseminni forskot á banka. Á 19. öld próast löggjöf og reglur um veðrétt og eignarrétt með svipuðum hætti í Danmörku og á Íslandi. Veðbækur í báðum pessum löndum eru áreiðanleg tól. Íslendingar fóru sér hægar í próun frjálsrar verslunar og hugsanlega var andstaða við borgarmyndun meiri á Íslandi. Félagafrelsið með dönsku stjórnarskránni 1849 kom ekki til Íslands og Landsbanki Íslands er nánast jafngamall íslensku stjórnarskránni 1874. RK-kerfið er aðgengilegt í Færeyjum, peir purfa að borga hærri umsýslupóknun en samkvæmt munnlegum heimildum verður RK-lán par samt ódýrara en bankalán. Í löndum par sem bankar eru sterkir er eðlilegt að mikil andstaða sé við innkomu nýrra kerfa.

Í Danmörku parf að líða mjög langur tími, 20 ár, frá gjaldproti áður en RK-skuld fyrnist. Pessi tími er mun lengri en lengst af hefur tíðkast á Íslandi. Til að RK-kerfið virki parf að vera til staðar mjög virkur skuldabréfamarkaður. Smæð íslenska skuldabréfamarkaðarins gæti verið vandamál. Á undanförnum árum hafa Íslendingar getað fjármagnað fasteignakaup með ríkisstyrktum verðtryggðum lánum. Frá árinu 2004 var ein opinber stofnun, Íbúðalánasjóður

${ }^{17}$ Ditlev (2009) vitnar til heimilda sem telja ríkjandi Evrópukerfi byggt á pýskum pfandebriefe og veðdeildum banka vera frábrugðin. Reynt var að útfæra RK-hugmyndir í Mexíkó eftir 1995. 
ráðandi aðili. Par á undan á tímabilinu 1989-2004 voru notuð húsbréf með ríkisábyrgð sem Húsnæðisstofnun ríkisins miðlaði. Pau mátti kaupa til baka á markaðskjörum (eða nafnvirði með áföllnum verðbótum) og voru að pví leyti hliðstæð RK-lánum. Uppgreiðslum skuldara mátti miðla til fjárfesta með aukaafborgunum (í formi útdráttar). Íbúðalánasjóður virðist ekki hafa verðlagt uppgreiðsluáhættu rétt og hugsanlega lent í vanda vegna pess. Íbúðalánasjóður gat pví lent í pví að sitja uppi með eigin skuldabréf. Pað er atriði sem dönsku RK-fyrirtækin lenda ekki í. Vextir á íslensku verðtryggðu lánunum hafa lengst af verið mun stöðugri en vextir á óverðtryggðum dönskum RK-lánum. Á síðustu árum hafa vextir á RK-lánum verið mun lægri en á íslenskum lánum. Pó hefur próun greiðslubyrði ekki lækkað samsvarandi pví að eignaverð í Danmörku hefur vaxið hraðar en á Íslandi. Vaxtalækkun er ekki kjarabót fyrir kaupendur ef höfuðstóll skuldar hækkar. Skuldastaða danskra heimila vegna húsnæðislána pykir há (bæði í sögulegu samhengi og í samanburði við önnur lönd). Umfjöllun Economist (19. apríl 2014) og reglur Evrópubandalagsins frá árinu 2007 ofl. eru vísbendingar um pað að útlendingar skilji RK-kerfið ekki vel. Pótt Danir séu ánægðir með sitt kerfi er ekki par með sagt að pað eigi greiða leið inn í önnur lönd. Eignarréttur og stofnanir sem tengjast honum byggja á hefðum sem ekki er auðvelt að hrófla við.

\subsection{Bankakerfið og Evrópusambandið}

Á seinustu 20 árum hefur RK-starfsemin í Danmörku tengst viðskiptabönkum sterkari böndum. Í munnlegum samtölum segja fulltrúar RK-fyrirtækja að RK-lán séu pað ódýr að bankar í öðrum löndum sjái sér ekki hag í að taka upp hugmyndina og myndu jafnvel beita sér gegn slíku. Fyrir Íslendinga sem hafa alist upp við forræði og afskiptasemi hins opinbera er pað hugsanlega framandi að sjá að pessi lánastarfsemi prífst vel með tiltölulega hófsömum ríkisafskiptum. Grunnhugmyndin, jafnvægishugmyndin (balance-prinsippet), pað аð eiginleikar láns séu í takt við eiginleika skuldabréfs sem fjármagnar lánið, pykir í dag góð og sjálfsögð áhættustjórnun í fjármálastarfsemi. RK-félögin taka ekki uppgreiðsluáhættu eins og til dæmis Íbúðalánasjóður og ekki vaxtabreytingaráhættu. Íbúðalánasjóður er par að auki nátengdur ríkisfjármálum á Íslandi. Kaupendur íbúðabréfa Íbúðalánasjóðs eru að kaupa eitthvað með ríkisábyrgð íslenska ríkisins, en kaupendur RK-skuldabréfa eru að kaupa skuldabréf hlutafélaga sem eru tengd veði í fasteignum. Frá 2007 með aukatryggingu SDO/SDRO skuldabréfa.

Í dag er RK-kerfið í nánum tengslum við bankakerfið. Рað eru margir sem ekki hafa áttað sig á pessu og ýmsir sem eru óánægðir með að gamla samábyrgðin skuli vera horfin. Hagfræðingurinn Astrup-Hansen(2014,2015) lýsir pví hvernig sumir halda að peir hafi tekið lán hjá félagasamtökum (forening), en vakna upp við pað að peir hafi tekið lán hjá hlutafélagi. Nykredit félagasamtökin eiga m.a. hlutafélögin Nykredit Bank A/S og Nykredit Realkreditaktieselskab. Nordea fjármálasamstæðan á Nordea Bank A/S, Nordea Realkredit A/S og einnig Nordeafonden. Nordeafonden er arfleifð frá kerfi sjálfseignarjóða. AstrupHansen talar um slíka sjóði sem juridisk ingenmansland , sem snarað á íslensku gæti hljómað „,fé án hirðis". Astrup-Hansen gefur í skyn að ný löggjöf um RK-félög hafi í raun eytt sérstöðu peirra. Í dag séu bara til lög um fjármálastarfsemi. Í Danmörku var einnig útbreitt sparisjóðakerfi. Sparisjóðum var gjarnan breytt í hlutafélög sem síðar gátu orðið hluti af fjármálakeðju eða góðgerðarstofnunum.

Núverandi RK-lánakerfi á sér langa hefð. Pótt kerfið sé nú mikið breytt frá pví sem upphaflega var lagt upp með og sé að mörgu leyti líkt veðlánakerfum víða í heiminum. Enn standa atriði eins og pað að félögin miðla vöxtum á markaði beint á milli lánveitenda og lántaka, pau safna ekki skuldabréfunum sjálf, skuldarar geta keypt bréf sín til baka á 
markaðsverði. Раð er mikil breyting frá pví að leyfð sé stofnun félagasamtaka með sameiginlega ábyrgð yfir í miðstýrðar Evrópureglur um fjármálastofnanir. Iversen og Brahm (2015) telja að Evrópureglur sem hafi fjármálastöðugleika í Evrópu að leiðarljósi séu í raun að gera lán dýrari fyrir Dani. Flokkunaraðferðir frá Brussel skilgreini mörg RK-skuldabréf sem illseljanleg. Par með séu pau ekki nothæf í lausafjárstöðu fjármálafyrirtækja sem krafist er af Basel-II reglum. Pví hljóti peir sem skulda lán í peim skuldabréfaflokkum að purfa að borga álag á vexti. Formaður Realkreditrådet tekur í svipaðan streng og telur Evrópureglur of bankamiðaðar. Ljóst er að prýstihópar í Brussel geta haft áhrif. Evrópureglur takmarka svigrúm stjórnvalda til að nota útlánareglur sem hagstjórnartæki. Realkreditrådet hefur opnað skrifstofu í Brussel. Traust á kerfinu byggir á að lánveitendur hafa alltaf fengið allt sem peim var lofað til baka og skuldarar geta ekki hlaupið frá skuldum sínum með gjaldproti. Pessi atriði stuðla að almennu trausti og lágum vöxtum. Afgerandi páttur er aðgengið að virkum markaði (Københavns fondbørs). Ef Evrópusambandið telur vissa flokka danskra skuldabréfa pað litla að peir verðskuldi sérstakt vaxtaálag vegna illseljanleika er hætt við að enn smærri íslenskir skuldabréfaflokkar fá enn harðari meðferð.

Danskur skuldabréfamarkaður byggir á langri sögu og sterkum hefðum. Pær hefðir verða ekki fluttar til annarra landa. Pegar Mexíkó lenti í vandræðum var hluti efnahagsúrræða tilraun til að taka upp danskt kerfi. Рað reyndist ekki auðvelt að setja upp innflutta hugmynd. Mikilvæg ástæða pess að danska RK-kerfið virkar er náið samspil við stofnanir eins og kauphöllina (Børsen), lögfræðihefðir um eignarétt og gjaldprot. Lönd eins og Svípjóð, Holland og Pýskaland notast öll við skuldabréfafjármögnun á húsnæði en útfærslur eru par mjög ólíkar. Umgengni við eignarrétt á húsnæði er ólík milli landanna og jafnvel innan Pýskalands. Рað er mjög erfitt að bera saman húsnæðiskerfi milli landa, bæði varðandi leigu-, eignarrétt og fjármögnun. Petta kemur glögglega fram í bók Lunde \& Whithead (2016). Par eru fjármögnunarkerfi ýmissa landa borin saman og ljóst að hefðir eru mjög mismunandi milli landa. Í munnlegum samskiptum við starfsmenn hjá Realkreditrådet og Realkreditforeningen (hagsmunasamtök RK fyrirtækja) kom ekki fram neinn áhugi á að reyna fyrir sér utan Danmerkur. Kreppan 2008 var að miklu leyti alpjóðleg bankakreppa. Hugsanleg skýring á pví hvers vegna danskur skuldabréfamarkaður stóðst alpjóðlegu bankakreppuna er að RKfyrirtækin standa af sögulegum ástæðum að miklu leyti utan við hefðbundið bankakerfi. Einnig er hin langa hefð fyrir jafnvægi inn- og útlána (balanceprincipen) mikilvægt atriði í áhættustjórnun. Ljóst er að á Íslandi hefur skort á hefðir og festu sem einkennt hefur danskt umhverfi. •að sem einkennt hefur íslenskt umhverfi eru tíðar kerfisbreytingar knúðar fram á vettvangi stjórnmála. Skuldabréfamarkaðir á Íslandi hafa verið minni og eiga sér skemmri sögu en í Danmörku. Í samanburði við danskar hefðir er pví hæpið að tala um íslenskt kerfi.

\section{Heimildir}

Andersen, J. V. \& Gyntelberg, J. (1999). Indeksobligationer. Danmarks Nationalbank Kvartaloversigt, 1. kvartal, 46-57.

Astrup-Hansen, J. (2014). Uden om realkreditten. Berlinske Business, 17.08.2014.

Astrup-Hansen, J. (2015). Nykredit - en forening eller hvad? Berlingske Business, 20.12.2015.

Astrup Jensen, B. (2013). Rentes regning. Jurist- og Økonomforbundets Forlag.

Babylon 10: Free Online Dictionary (2014). Hypotekslån. (Sótt 10. febrúar 2015 af http://www.babylon.com/definition/hypoteksl\%C3\%A5n/) 
Bergsøe, A. (1839). Motiveret Udkast til en Creditforening for Danske Grundbesiddere. C. Groebe \& son.

Boligministeriet (1987). Den fremtidige realkreditlovgivning: Redegørelse. Boligministeriet, Boligstyrelsen og Byggestyrelsen.

Bordo, M. D. \& Filardo, A. J. (2005). Deflation in a historical perspective. BIS working paper 186, BIS.

BRFKredit (2014). Realkreditsystems historie. (Sótt 10. febrúar 2015 af https://www.brf.dk/Investors-Dansk/Realkreditsystemet/Realkreditsystemet/Danskrealkreditsystems-historie)

Callø, P. (1932). Realkrediten under skiftende konjunkturer. Nationaløknomisk Tidsskrift, Række 40 (Bind 3.), 219-314.

Campbell, J. Y. (2013). Mortgage market design. Review of Finance, 17, 1-33.

Campbell, J. Y. \& Cocco, J. F. (2003). Household risk management and optimal mortgage choice. Quarterly Journal of Economics, 118, 1449-1494.

Deacon, M., Derry, A., \& Mirfendereski, D. (2004). Inflation-indexed securities: Bonds, swaps and other derivatives. Hoboken, NJ, John Wiley \& Sons.

Demarzo, P. \& Duffie, D. (1999). A liquidity-based model of security design. Econometrica, 67(1), 65-99.

Ditlev, C. (2009). SDO lån og deres betydning for det danske boligfinansieringsmarked. Master's thesis, Handelshojskolen i Århus Universitet.

Economist (2014). Danish mortgages: Something rotten, Denmark's property market is built on rickety foundations. Economist, 19. apríl 2014.

Fisher, I. (1930). The Theory of Interest. Library of Economics and Liberty.

Frankel, A., Gyntelberg, J., Kjeldsen, K., \& Persson, M. (2004). The Danish mortgage market. BIS Quarterly Review, (1), 95-109.

Gils Guðmundsson (1946). Skútuöldin Síðara bindi. Bókaútgáfa Guðjóns Ó. Guðjónssonar.

Haldrup, K. (2014). On security of collateral in Danish mortgage finance: a formula of property rights, incentives and market mechanisms. European Journal of Law and Economics, 1-29.

Iversen, C. \& Brahm, K. (2015). Forskere: Usaglige EU-regler giver højere renter til boligejere. Finans 21.12.2015.

Lunde, J. (2012a). Husholdningsgælden. Finans/Invest, (6), 18-24.

Lunde, J. (2012b). Impacts on Wealth and Debt of Changes in the Danish Financial Framework Over a Housing Cycle. Kafli 7 í Challenges of the Housing Economy (128-152), Ritstjórn, C. Jones, M. White og N. Dunse, Wiley-Blackwell.

Lunde, J. \& Whitehead, C. (2016). Milestones in European Housing Finance. Wiley-Blackwell.

Meric, H. \& Sørup, R. (2010). Effectivitet på den danske obligationsmarked. Cand. Merc ritgerð, Handelshøjskolen København.

Møller, M. \& Nielsen, N. C. (1997). Dansk realkredit gennem 200 aar. BRF.

Nielsen, S. \& Risager, O. (2001). Stock returns and bond yields in Denmark, 1922-1999. Scandinavian Economic History Review, 1, 63-82.

Pedersen, N. B. (2010). Investors retsstilling $i$ tilfxld av realkreditinstituttets konkurs. Master's thesis, Copenhagen Business School.

Rasmussen, K. M., Madsen, C., \& Poulsen, R. (2011). Realkreditrådgivning: Et studie af danskernes valg af realkreditlån og konverteringspraksis. Bolig Ökonomisk Videncenter.

Realkreditrådet(1997) Realkreditrådet i 25 år-jubilæumsskrift. Realkreditrådet.

Realkreditrådet (2012). Den klassiske danske realkreditmodel. Realkreditrådet.

Porgeir Örlygsson (2002). Veðréttur. Bókaútgáfa Orators. 